\title{
High-resolution tentaculite biostratigraphy and facies development across the Early Devonian Daleje Event in the Barrandian (Bohemia): implications for global Emsian stratigraphy
}

\author{
LENKA FERROVÁ, JIŘí FRÝDA \& PAVEL LUKEŠ
}

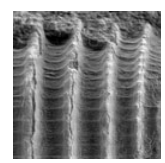

\begin{abstract}
The long-term activities of the International Subcommission on Devonian Stratigraphy have been focused on the division of the Emsian into two new substages. The different stratigraphic levels, close to the Daleje Event, have mostly been discussed as their boundary. The latter event was first recognized in the Barrandian and defined as a bioevent, connected with a pronounced transgression. Its present conception has been inferred from studies of its appearance in deeper environments, with deposition of the calcareous Daleje Shale. We analysed its appearance in shallower environments, with predominantly carbonate sedimentation, using precise qualitative and quantitative biostratigraphic, paleoecological, and sedimentological methods. Our data revealed that the mid-Emsian had a more complex transgression-regression history than previously described. Evaluation of the stratigraphic distribution of more than 1250 newly collected dacryoconarid shells has resulted in the proposal of a new tentaculite biozonation, providing a much higher stratigraphic resolution than the existing biozonations, which are based on goniatites and conodonts. Quantitative analysis of the newly gathered paleoecological data suggests a distinct faunal turnover at the level of the first occurrence of the dacryoconarid tentaculite Nowakia elegans. In addition, our study revealed that the Daleje transgression (and thus the Daleje Event) started at the same time, and that it was preceded by a distinct regression. For these reasons, we propose the first occurrence of the worldwide and easily determinable dacryoconarid Nowakia elegans as a biostratigraphic indicator of the boundary level for the new Emsian substages. $\bullet$ Key words: Early Devonian, Daleje Event, Palaeozoic, new tentaculite biostratigraphy, facies analysis.
\end{abstract}

FERROVÁ, L., FRÝDA, J. \& LUKEŠ, P. 2012. High-resolution tentaculite biostratigraphy and facies development across the Early Devonian Daleje Event in the Barrandian (Bohemia): implications for global Emsian stratigraphy. Bulletin of Geosciences 87(3), 587-624 (17 figures, 1 table). Czech Geological Survey, Prague. ISSN 1214-1119. Manuscript received December 30, 2011; accepted in revised form September 4, 2012; published online September 14, 2012; issued September 28, 2012.

Lenka Ferrová, Klárov 3/131, Czech Geological Survey, P.O.B. 85, 11821 Prague 1 and Institute of Geology and Paleontology, Charles University in Prague, Albertov 6, 12843 Prague 2, Czech Republic; Lenka.Ferrova@seznam.cz•Jiři Frýda, Faculty of Environmental Sciences, Czech University of Life Sciences Prague, Kamýcká 129, Praha 6-Suchdol, 16521 and Czech Geological Survey, P.O.B. 85, 11821 Prague 1, Czech Republic; bellerophon@seznam.cz・Pavel Lukeš, Třebešovská66/561, 19300 Prague,Czech Republic; hopo66@seznam.cz.

The Early Devonian marine ecosystem was strongly influenced by several global changes, which were linked with restructuring of the marine food webs. The increased input of organic matter into the ocean, which was caused by the rise of land plants, dramatically changed the chemistry of the ocean surface waters (Algeo \& Scheckler 1998). This eutrophication gave rise to plankton blooms, and opened up a new food source for many marine swimming organisms. Subsequently, the new food source structures caused changes in ontogenetic strategies and/or radiation of some groups of invertebrates and vertebrates (e.g., Signor \& Brett 1984; Bambach 1999; Nützel \& Frýda 2003; Klug
\& Korn 2004; Klug et al. 2008, 2010; Monnet et al. 2011a, De Baets et al. 2012, and references therein). In addition, repeated and lasting events of anoxia caused selections in favour of non-benthic and demersal life styles (e.g., Klug et al. 2010; Manda \& Frýda 2010). Klug et al. (2010) showed that during the Devonian, demersal and nektonic modes of life were probably initially driven by competition in the diversity-saturated benthic habitats, together with the availability of abundant planktonic food. Fundamental evolutionary changes in the Devonian marine water column were linked with the rapid rise of nekton (i.e., "Devonian nekton revolution", Klug et al. 2010). On the other hand, increasing 
predation pressure on the new Devonian planktonic groups (e.g., Berkyová et al. 2007) as well as the new food sources influenced evolution in the majority of marine invertebrates (Klug et al. 2010). For example, three of the five living gastropod orders, which form the most diversified of all living marine invertebrate groups, probably originated during the Early Devonian (Bandel 1997; Nützel 1998; Frýda 2012; Frýda et al. 2008a, 2009; Frýda \& Blodgett 2004; Nützel et al. 2007a). Increasing predation pressure and the existence of new food sources in the ocean surface waters is also linked with the extensive changes in gastropod protoconch morphology and adaption of some new groups on larval planktotrophy (Nützel \& Frýda 2003; Nützel et al. 2006, 2007a, b; Frýda et al. 2009; Seuss et al. 2012).

Taken together, the Early Devonian marine ecosystem was quickly developing and changing in all of its environments (see review in Klug et al. 2010, and references therein). For an understanding and analysis of the Early Devonian evolutionary processes and the evolution of the marine environments, a very precise dating of Lower Devonian sedimentary successions is needed. However, the recent state of biostratigraphic zonation of the Early Devonian is too inaccurate for many evolutionary, ecological, and biogeographic analyses.

Long-lasting activities of the International Subcommission on Devonian Stratigraphy (ISDS) have been focused upon improving the precision of the Devonian biostratigraphic zonation. In recent years, one of the most discussed topics at the ISDS is about splitting the Emsian into two substages (see review in Becker 2007, Becker et al. 2010, Carls \& Valenzuela-Ríos 2007, Kim et al. 2012). The main reason for this is the extremely long duration of the Emsian, in comparison with other Devonian stages. Its duration is estimated to be about $17 \mathrm{Ma}$ by Kaufman (2006), or about $10 \mathrm{Ma}$ according to the International Stratigraphy Chart (2011); this would be more than twice the duration of the other Early Devonian stages - Lochkovian (6 Ma or $5 \mathrm{Ma}$ ) and Pragian (3 Ma or $4 \mathrm{Ma}$ ), respectively. Additionally, the extremely long duration of the Emsian has been negatively influenced by the present definition of its lower boundary (see Carls et al. 2008 for details). The ISDS has suggested splitting the Emsian into two substages, the duration of which will be the same (or even longer) as that of two other Early Devonian stages (i.e., Lochkovian and Pragian). The reason for calling them substages (except for the efforts to save the historical name Emsian) is not clear, and they could be really be named as stages.

The boundary of the regional Zlíchovian and Dalejan stages (established in the Barrandian), or the stratigraphic level close to their boundary, have mostly been discussed as time levels for the boundary of the new global substages (stages) of the Emsian (see details in Chlupáč \& Lukeš
1999, also in Becker 2007). The Zlíchovian and Dalejan were established for practical reasons during a period of field mapping several decades ago. The whole Emsian succession of the Barrandian (Fig. 1) is mostly formed by carbonates (with the only exception in the middle of the Emsian). At that time, an interval of calcareous shales (the Daleje Shale) was deposited in most of the environments. The latter stratigraphic unit was recognized almost 200 years ago (e.g., Barrande 1846a, b), but formalized much later by Krejčí (1877). During an intensive mapping period (1946-1960) and the associated biostratigraphic research after the Second World War (Svoboda \& Prantl 1947-1951, Chlupáč 1954-1960), as well as during later activities focused on the proposal of the Early/Middle Devonian boundary in the Barrandian (Chlupáč et al. 1978, 1998; Chlupáč \& Lukeš 1999 and references therein), huge amounts of new sedimentological, biostratigraphic, and palaeontological data was gathered from many Barrandian sections. All of these activities resulted in a redefinition of the Zlíchovian and Dalejan, which have been used since that time not only as regional stages, but also as internationally useful chronostratigraphic units (e.g., De Baets et al. 2010). However, for somewhat obscure reasons, they were not accepted as international stages or substages. In 2003, the International Subcommission on Devonian Stratigraphy decided to divide the Emsian into two substages named as the Lower and Upper Emsian (SDS Newsletter 19). Names were selected; but no definition of their boundary exists so far.

As summarized by Becker (2007): "There is general agreement that the substage boundary should lie close to the Zlíchovian/Dalejan boundary of the Bohemian succession (Chlupáč 1976, Chlupáč \& Lukeš 1999), which is characterized by the supposedly global and transgressive Daleje Event (House 1985)". The Daleje Event was defined by House (1985) as an "extinction event", which is connected with the Dalejan transgression. Thus, the Daleje Event was defined as a bioevent based on the extinction of some groups of early goniatites (i.e., some Mimosphinctidae and the Auguritidae). However, Chlupáč \& Kukal (1988, p. 125) used this term for an event having "a global character and manifests itself by a gradual rise of sea level, deepening of basins which were often accompanied by clay deposition at the expense of carbonate sediments". Chlupáč \& Kukal (1988) thus used the term "Daleje Event" for a transgressive event (also see Becker \& Kirchgasser 2007). Unfortunately, such terminological chaos is rather common for some Palaeozoic events (e.g., Silurian/Devonian boundary events; Manda \& Frýda 2010), and has resulted in some complicated scientific discussion. In the present paper, we use the term "Daleje Event" in the sense of Chlupáč \& Kukal (1988) because this usage has prevailed in the published scientific papers. It is noteworthy that the Daleje Bioevent was based by House (1985) on the 


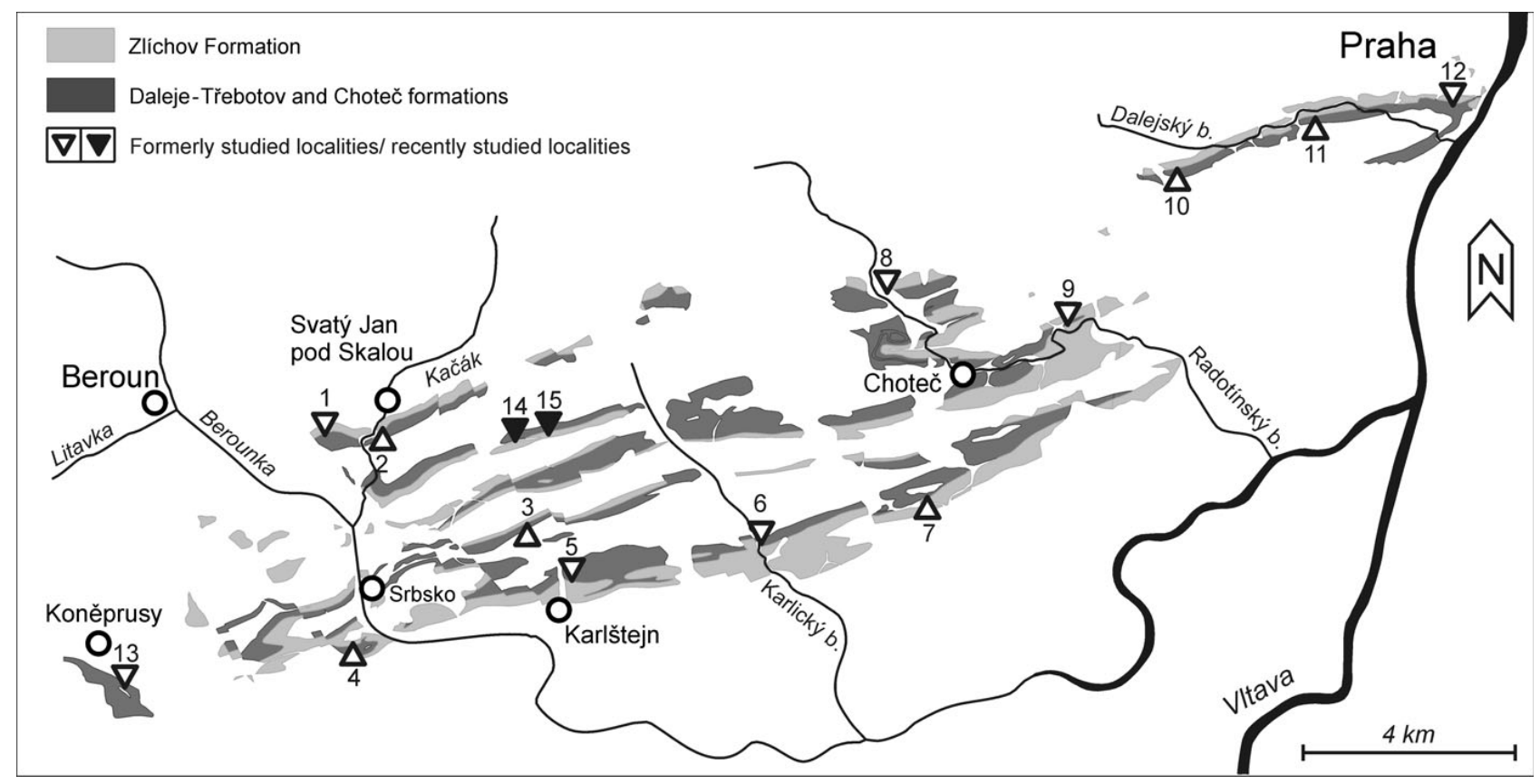

Figure 1. Map showing geographic distribution of Zlíchov, Daleje-Třebotov, and Choteč formations in the Barrandian, as well as the position of the most important localities. 1 - Macháčkův lom near Hostim; 2 - Kačák Valley; 3 - Amerika quarry; 4 - Císařská rokle near Srbsko; 5 - Karlštejn V Hlubokém Valley; 6 - Karlík Valley; 7 - Pekárkův mlýn near Solopisky; 8 - Rážův mlýn; 9 - Kominická rokle; 10 - Zabitá rokle; 11 - Klukovice; 12 - Švagerka; 13 - Červený lom near Suchomasty; 14 - Čeřinka hillside; 15 - Čeřinka quarry.

supposedly coeval extinction of the family Auguritidae and some Mimosphinctidae, which in total represents the extinction of six genera of goniatites, according to House (1989). Nevertheless, there is no doubt that the period close to the Zlíchovian/Dalejan boundary is linked with a fast faunal turnover, as has already been noted by many earlier scientists (e.g., Chlupáč \& Lukeš 1999).

Regardless of the usage of the term "Daleje Event", the Barrandian is a classical area where this Emsian event was first recognized and defined (see House 1985, Chlupáč \& Kukal 1988). However, its appearance was primarily studied in areas with the deposition of the calcareous Daleje Shale. The main focus of the present study is to evaluate facies development across the Daleje Event in carbonate-dominated environments of the Barrandian (Bohemia) and to improve the biostratigraphic zonation based on the dacryoconarid tentaculites of this interval, as well as to discuss the implications for global Emsian stratigraphy.

\section{Lithostratigraphic units at the Daleje Event interval}

More than 200 years of investigation of the Emsian successions, as well as their faunas in the Barrandian, have brought forth several hundred published and unpublished studies, written mainly in Czech, English, French, and German. In addition, during such a long time, the names of the localities as well as of the lithostratigraphic units were changed several times, along with their definitions and usage. Therefore, orientation within the published data is very difficult (or nearly impossible) for foreign scientists. Because of this, an overview of the basic data on the main lithostratigraphic units at the Early Devonian Daleje Event interval is presented here.

As previously mentioned, the Daleje Event was first established as a bioevent; however, this term is mostly used as an equivalent for a distinct transgression that occurred in the middle of the Emsian. The Daleje Event occurs close to the boundary of the Zlíchov and Daleje-Třebotov formations. The older Zlíchov Formation forms two lithological units - the Zlíchov Limestone and Chýnice Limestone. For the purposes of this paper, the Chýnice Limestone is described separately from the Zlíchov Limestone, although Chlupáč (1981) had considered the Chýnice Limestone to be a member of the Zlíchov Limestone. The younger Daleje-Třebotov Formation includes three lithological units the Daleje Shale plus the Třebotov and Suchomasty limestones. The stratotypes of these lithological units are described by Chlupáč (1957) and in Chlupáč et al. (1998). In the following section, we briefly summarize the basic information on all lithostratigraphic units described from this stratigraphic interval in the Barrandian, as well as describing the usage of these terms in the present paper. The lithostratigraphic units are listed in their stratigraphic order. 


\section{Zlíchov Limestone}

In his paper, Kettner (1917) described the geology of the Zlíchov Limestone of the southern suburb of Prague as the first recognized independent sedimentological cycle in the upper half of the so-called Braník limestone (the "Bande g1" of Barrande). Later, Kodym (1919) as well as Kettner \& Kodym (1919) introduced the name Zlíchov Limestone for this lithological unit. Lithological developments of the Zlíchov Limestone were studied and described in detail by Svoboda \& Prantl (1948a, b) as well as Chlupáč (1957). The latter author slightly modified the usage of this term, and in 1981, he noted that the term Zlíchov Limestone should be considered as a valid synonym to the Zlíchov Formation. In some areas, the uppermost portion of the Zlíchov Limestone reaches to the stratigraphic level of the Daleje Event.

Generally, the facial differentiation of the Zlíchov Limestone is low. The predominant volume of this lithological unit is formed by thin bedded, dark to light grey, fine detrital to micritic limestones with abundant black cherts along with minor intercalations of calcareous shales. The majority of micritic layers and most of the shale intercalations are burrowed by Chondrites (Chlupáč 1957). In the lowermost part of the Zlíchov Limestone in the NE and SE areas of the Barrandian, the so-called "Chapel Coral horizont" described by Kettner (1917) is developed; for more details on the informal "Kaplička" unit or "Chapel horizont" see Svoboda \& Prantl (1948a), Chlupáč \& Lukeš (1999), and Chlupáč et al. (1998). Chlupáč \& Lukeš (1999, p. 80; Chlupáč et al. 1998) used the term "Chapel Member" or "Chapel Coral Horizon" for this unsorted, coarse sedimentary breccia, and Hladil et al. (2010, p. 391) used a genetic term of channelized breccia flow deposits.

There are two basic types of transitions of the Zlíchov Limestone to younger lithological units: to $(a)$ the Chýnice Limestone and $(b)$ the Daleje Shale. A typical feature of the uppermost part of the Zlíchov Limestone is the disappearance of (or the very low occurrences of) dark cherts. This trend had already been observed by Kettner (1917) in the southern suburb of Prague, and later documented in all studied sections of the Barrandian (e.g., Svoboda \& Prantl 1947-1951, Chlupáč 1957, Chlupáč et al. 1979, Chlupáč \& Lukeš 1999). The upper layers of the Zlíchov Limestone in the SE and S parts of the Barrandian are developed as grey, well-bedded, Chondrites-bearing limestones without cherts, intercalated with subordinate layers of dark shales (Chlupáč et al. 1979, Chlupáč \& Lukeš 1999). In this area, the number of calcareous shale beds gradually increases upwards, and the stratigraphically higher shales predominate over the limestone beds (a gradual transition of the Zlíchov Limestone to the Daleje Shale). However, in the NW part of the Barrandian, the upper part of the Zlíchov Limestone is formed by grey to light-grey micritic and finely detrital, well bedded, Chondrites-bearing limestones without cherts. Compared with the underlying beds, the amount of biodetritus increases slightly upwards, containing mainly trilobite, ostracod, and brachiopod fragments (e.g., Chlupáč et al. 1979). These layers gradually, but rapidly, change into a rosy, coarsely grained Chýnice Limestone.

\section{Chýnice Limestone}

In 1948, Svoboda \& Prantl published the results of their geological mapping in the neighbourhood of the village of Chýnice (SE of Prague), where they found rose or red coarse-grained limestones overlying the Zlíchov Limestone, and named these the Chýnice Limestone. Svoboda \& Prantl (1948) discussed the geographic distribution of the Chýnice Limestone and noted their occurrence in many sections of the NW, N, and NE parts of the Barrandian. Their later mapping activities (Svoboda \& Prantl 1948-1951) revealed that the Chýnice Limestone was not developed only in the SE and S parts of the Barrandian, where a gradual transition of the Zlíchov Limestone into the Daleje Shale is developed.

In general, the Chýnice Limestone is lithologically rather variable in the ratio of coarse-grained bioclastic to finer bioclastic or micritic components. Their colour also varies from rosy to dark red brown, depending on the content of iron oxides. The lower boundary of the Chýnice Limestone with the Zlíchov Limestone is often gradual, but always rather sharp (the thickness of the transition interval is usually only a few centimetres - e.g. Fig. 2B, C). Development of the lower and upper parts of the Chýnice Limestone differs (Chlupáč 1957, Chlupáč et al. 1979, Havlíček \& Vaněk 1996); however, a detailed sedimentological analysis has never been done. The lower part mainly consists of light to rosy granular biodetritic limestones with abundant diversified trilobites, ostracods, and other fauna. On the other hand, in the upper part of the Chýnice Limestone, the amount of the micritic component is high and gradually increases upwards and they become darker (red to red-brown). The lower beds of this more richly micritic upper part bear a rich and diversified benthic fauna, mainly comprising corals, trilobites, and brachiopods (e.g. Čeřinka hillside and Zabitá rokle localities).

The upper boundary of the Chýnice Limestone is typically formed by a gradual transition to the Daleje Shale. However, in the vicinity of village of Svatý Jan pod Skalou (Bubovice, Boubová Hill, Stydlé vody, Kačák Valley near Hostim, Mramorka Hill), the Chýnice Limestone gradually and very slowly changes into the Třebotov Limestone of the Daleje-Třebotov Formation (see discussion below). The thickness of the Chýnice Limestone reaches maximal values (up to $15 \mathrm{~m}$ ) in areas where the Daleje Shale is not 

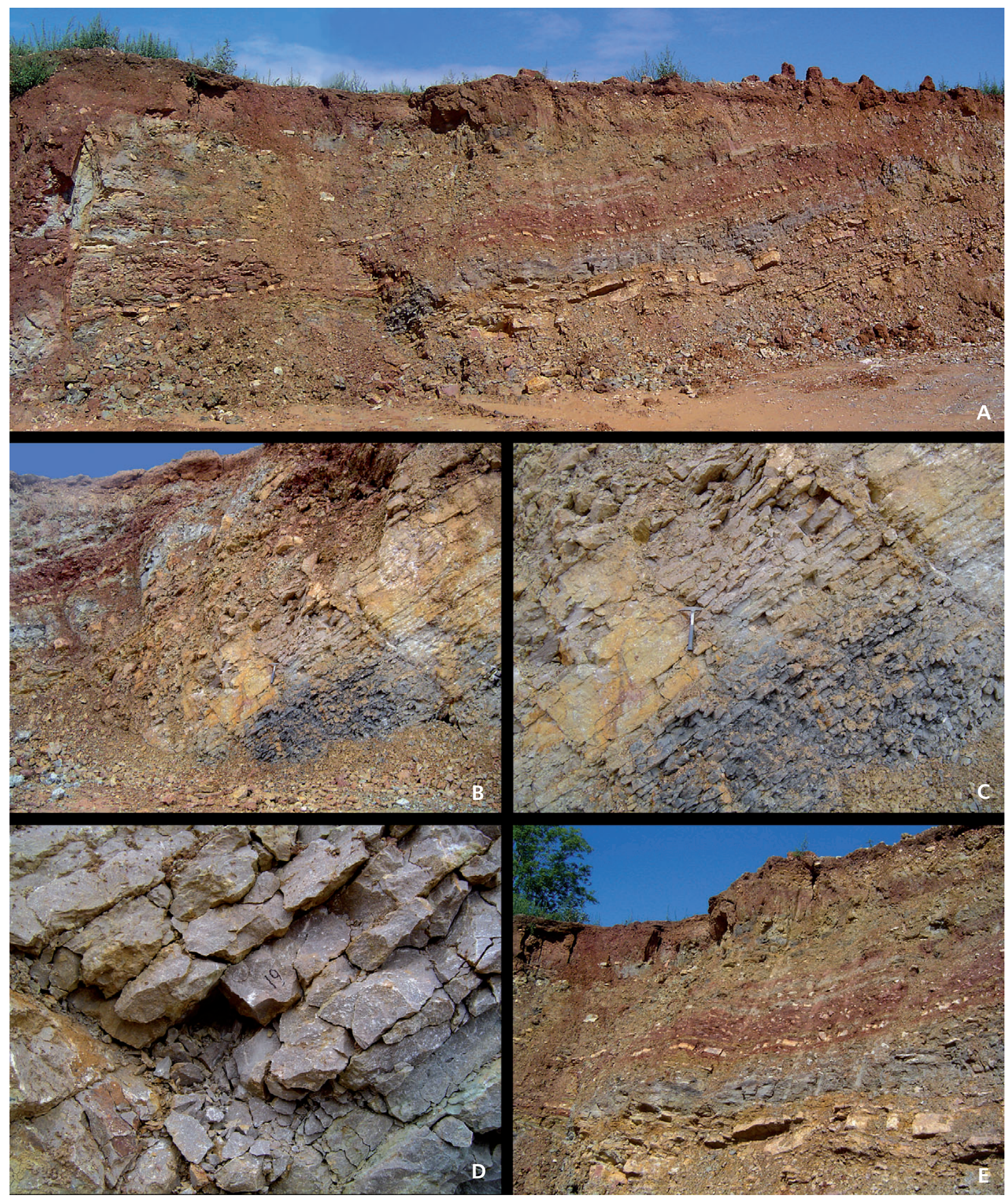

Figure 2. Čeřinka quarry section. • A, B - view of the section, including the upper part of the Zlíchov Limestone, Chýnice Limestone, and Daleje Shale. - C - transition from the Zlíchov Limestone (dark grey colour) to the Chýnice Limestone (pink colour). $\bullet$ - detail of picture C. $\bullet$ E - transition from the Chýnice Limestone (light reddish colour) to the Daleje Shale (grey to red colour). 
developed, and gradually decreases toward the S, SE, E, and NE.

The original stratotype of the Chýnice Limestone was established by Svoboda \& Prantl (1948) near the village of Chýnice. Unfortunately, this locality ceased to exist, and for that reason, a new lectostratotype was established in the Macháčkův lom near Hostim by Chlupáč (1957). In this area, however, it is difficult to define the upper boundary of this unit using lithological features (see discussion below).

\section{Daleje Shale}

Krejčí (1877) was the first who formally named the Daleje Shale (his "Daleje Band"). Usage of this lithological name was later redefined by Chlupáč (1959). The Daleje Shale is typically developed as greenish or dark grey-green calcareous shales. The colour of the Daleje Shale gradually changes to red or dark red in the uppermost parts. It is commonly bioturbated (Chondrites burrows), and in some sections, it contains grey micritic limestone concretions or thin beds. Krejčí did not establish the stratotype of the Daleje Shale and thus, the outcrop at the road "Ke Hřbitovu" in Praha-Hlubočepy was selected as the new lectostratotype (Chlupáč et al. 1998). Chlupáč (1959) defined the level at which shales predominate over limestones (Zlíchov or Chýnice limestones) as the lower boundary of the Daleje Shale unit. The distribution of the Daleje Shale varies across the Barrandian. The maximal thickness (more than $50 \mathrm{~m}$ ) is developed in the SW vicinity of Prague (e.g. Praha-Hlubočepy, Třebotov; Chlupáč et al. 1998). A detailed description of their lithology, geographic distribution, and chemistry may be found in Kodym (1924), Petránek (1951), Svoboda et al. (1957), Chlupáč (1959), and Chlupáč et al. (1998).

\section{Třebotov Limestone}

The term Třebotov Limestone was introduced by Svoboda and Prantl (1947) for the red coloured mostly micritic limestones forming the lower part of the so-called Hlubočepy limestones. Later, Chlupáč (1959) redefined the usage of this lithological name and united the younger grey micritic limestones with the underlying red coloured Třebotov limestones of Svoboda \& Prantl (1947) under his Třebotov Limestone. This definition of the Trrebotov Limestone is still in use.

The Třebotov Limestone is typically represented by well-bedded, nodular, red, micritic limestones gradually changing colour upwards into a light grey. Volcanic activity within this member is documented in the vicinity of Chýnice and Choteč (Fiala 1946, Svoboda \& Prantl 1948). Further detailed information on their geology and faunas can be found in Svoboda \& Prantl (1947-1951), Chlupáč (1959, 1998), Chlupáč et al. (1998), and Vodrážková et al. (2012). The "Nad tratî" quarry section at Praha-Hlubočepy was selected as the lectostratotype of this lithostratigraphic unit (Chlupáč 1959, 1981). The boundary of the Třebotov Limestone with the underlying Daleje Shale is gradual, and was defined by Chlupáč (1959) as the "level where the amount of limestones predominates over shales". However, the definition of the lower boundary of the Třebotov Limestone with the underlying Chýnice Limestone is unclear in those areas with missing shale sedimentation such as in the vicinity of the village of Hostim (see discussion below).

\section{Suchomasty Limestone}

The term Suchomasty Limestone was formally introduced by Chlupáč (1957) for coarse red crinoidal to micritic limestones, only occurring in the Koněprusy area. The dominant colour of the Suchomasty Limestone is dark red, with its thickness reaching up to $30 \mathrm{~m}$. These limestones were deposited on top of the Koněprusy Limestone (Praha Formation, Pragian) after a long period of emersion and erosion, being equivalent to the lower Emsian (Zlíchovian). The lower part of the Suchomasty Limestone also includes the filling of Neptunian dykes (Chlupáč 1954, 1996). The Suchomasty Limestone represents a partial equivalent of the Chýnice Limestone, and the full equivalent of the Třebotov Limestone (for further detailed information see Chlupáč 1954, 1996; Havlíček \& Kukal 1990). The Červený lom near Koněprusy was selected as the lectostratotype of the Suchomasty Limestone by Chlupáč (1981).

\section{Methods}

A review of all of the published data was used to select the sections, which are the most suitable for analysis of the appearance of the Daleje Event in successions with predominantly carbonate sedimentation. Two sections, the Čeřinka hillside and the Čerrinka quarry, were selected for the present study. The first locality had been partly studied in the past (see references in Havlíček \& Vaněk 1996); however, the second section was discovered by one of us (JF) in 2006 during field research. Since 2006, both sections have been

Figure 3. Čeřinka hillside and Čeřinka quarry sections showing the lithology, biostratigraphy, and bed (interval) numbers. Dashed line - newly proposed lower boundary of Dalejan. 
Čerinka hillside section

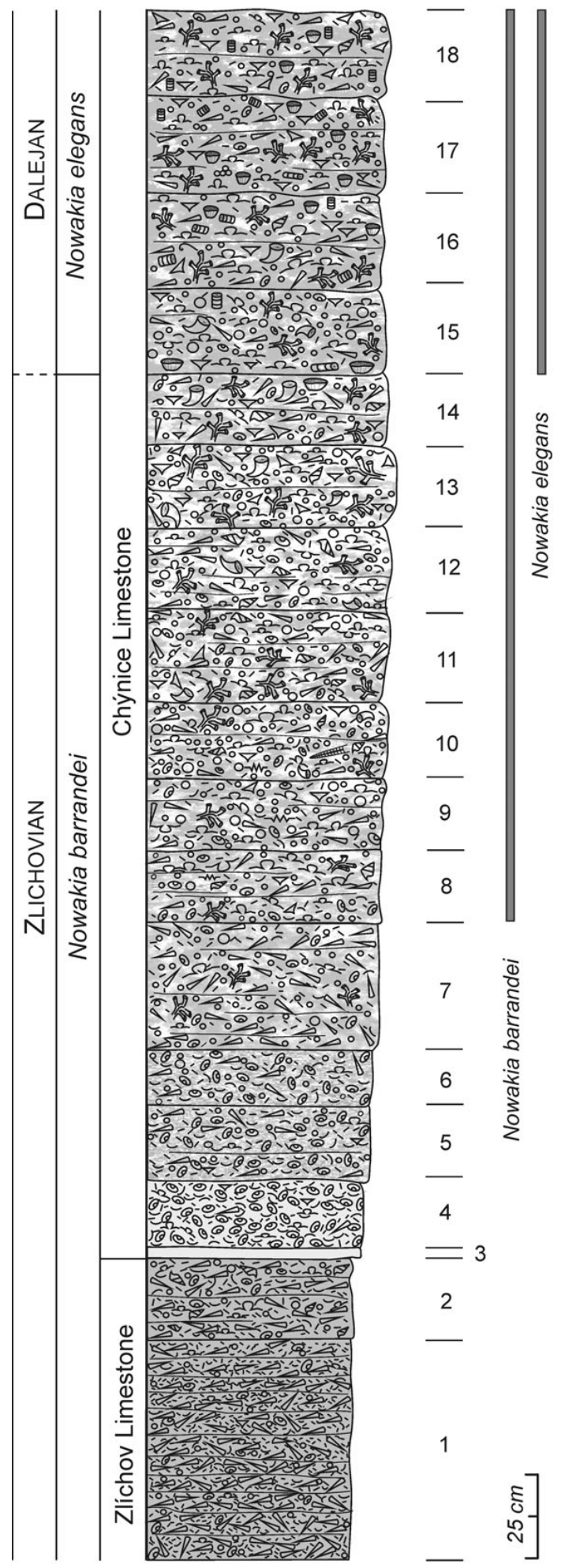

位 fine bioclasts

-1w- stylolites

自 crinoid stems

$\checkmark$ stratigraphic gap

proportion of clay particles in matrix

\section{Čeřinka quarry section}

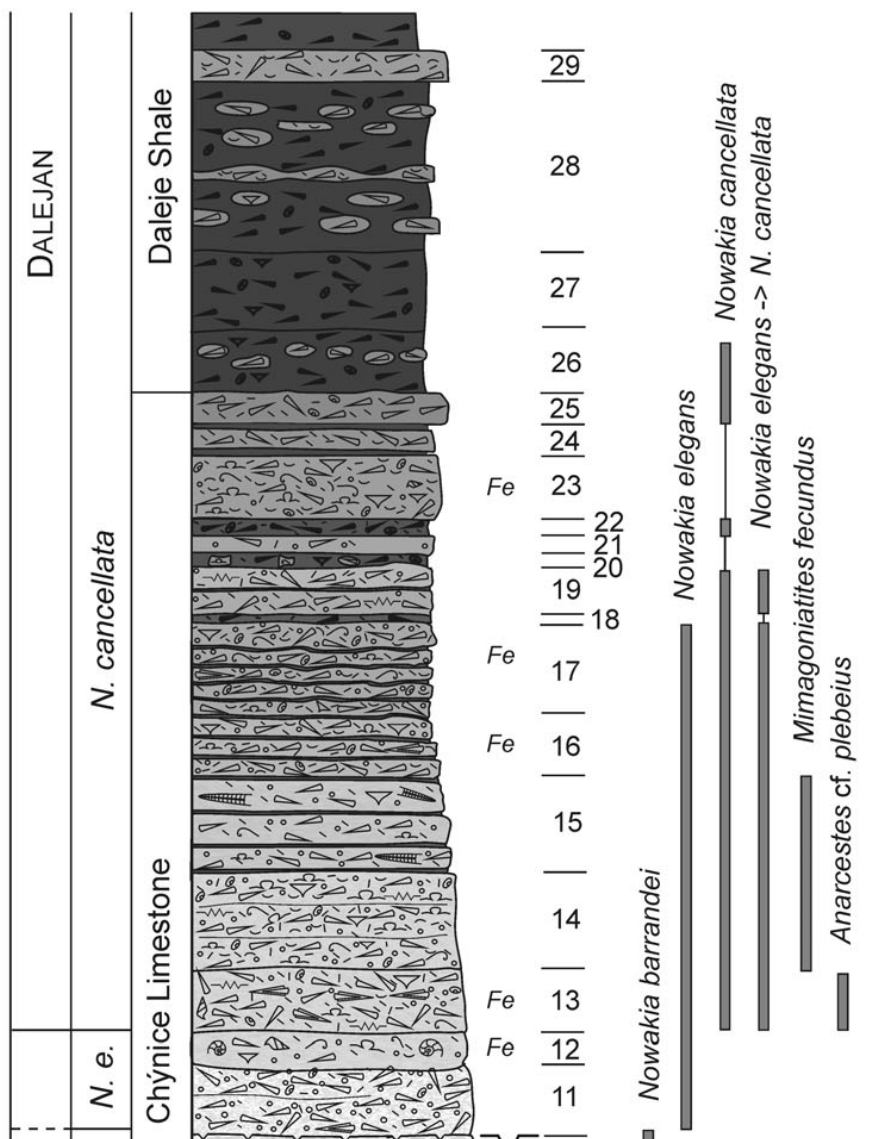

10

9

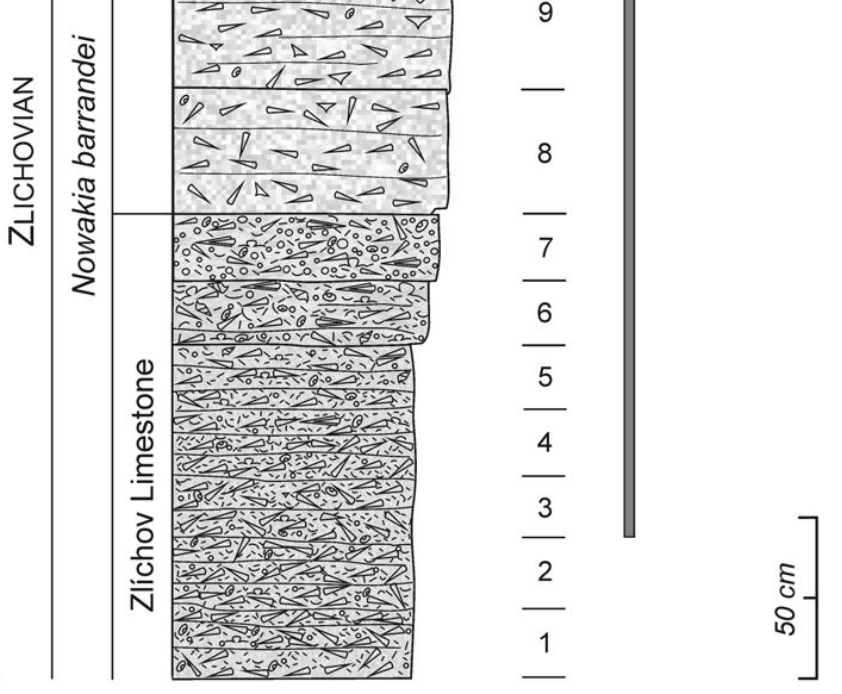

$\theta$ Tabulate corals

9 Rugose corals

$\searrow$ Brachiopods

(2) Cephalopods

Gastropods
Bivalves

$\triangle$ Tentaculitids

$\Omega$ Trilobites

Q Ostracodes

○ Crinoids 
intensively studied for the masters and later for the doctoral project of the senior author of this paper. The Čeřinka hillside was opened with a $25 \mathrm{~m}$ long trench, which makes the collection of large rock samples possible. For practical reasons, the section was divided into short intervals having thicknesses of 20 to $25 \mathrm{~cm}$ and numbered in stratigraphic order. Rock samples (about $20 \mathrm{~kg}$ ) from each interval were taken to the laboratory for palaeoecological, biostratigraphic, and sedimentological analysis, where also all the contained fossils were determined and counted. Only the data from the first $4.5 \mathrm{~m}$ of the Čerinka hillside section were used for the present study (the remainder of the samples are currently being studied by Lenka Ferrová).

The limestone succession at the Čeřinka quarry section makes the study of very fresh limestone beds possible (Fig. 2). For this reason, the entire section was not divided into artificial stratigraphic intervals as at the Čeřinka hillside section and bed-by-bed-sampling was used. The thickness of the studied intervals was determined according to the lithological features of the individual beds, with their thicknesses ranging from several $\mathrm{cm}$ to several $\mathrm{dm}$. The different thicknesses of the sampled intervals resulted in a different sampling strategy than at the Čerinka quarry section. The sample size was determined according to the interval thickness. From each $10 \mathrm{~cm}$ of thickness, a sample of $3 \mathrm{~kg}$ was taken, in order to maintain approximately the same sample density across the section. Samples coming from the Čerinka quarry section were processed in the laboratory as were those from the Čeřinka hillside section. Because of the fresh nature of the samples coming from the Čeřinka quarry section, about 35 samples were analysed for their isotopic composition of carbonate carbon. A few milligrams of rock powder (preferably micrite) were recovered with a dental drill from rock samples. Carbonate samples were decomposed in a vacuum by $100 \%$ phosphoric acid at a temperature of $25{ }^{\circ} \mathrm{C}$. The carbon and oxygen isotopic composition of the released $\mathrm{CO}_{2}$ was measured with a Finnigan Mat 251 mass spectrometer. All values are reported in \%o relative to $\mathrm{V}$-PDB by assigning a $\delta^{13} \mathrm{C}$ value of $+1.95 \%$ and a $\delta^{18} \mathrm{O}$ value of $2.20 \%$ to NSB 19 . Accuracy and precision were controlled by replicate measurements of laboratory standards and were better than $\pm 0.1 \%$ o for both carbon and oxygen isotopes.

The lithology of both sections was studied by the method of microfacial analysis, using thin sections of $3 \times 4 \mathrm{~cm}$ and $2 \times 4 \mathrm{~cm}$ in size. The quantitative data on all fossil taxa were summarized by Ferrová (2010), and have been prepared for publication. For numerical evaluation of the newly gathered data, the Past 2.15 software package was used (Hammer et al. 2001).

In the present paper, only the data on dacryoconarid tentaculites are used for improvement of the biostratigraphic resolution at the particular studied interval. Herein, the basic data on the stratigraphic distribution of all newly found tentaculites in the Daleje Event interval at both of the studied sections are briefly summarized, together with a list of all of published as well as hitherto unpublished (dataset of Pavel Lukeš) occurrences in the Barrandian. We stress that the newly gathered data represents the first quantitative dataset on the stratigraphic distribution of dacryoconarid tentaculites across the studied interval. All previously published biostratigraphic data were only collected qualitatively (i.e., an absent/present dataset). The latter approach resulted in a much lower stratigraphic resolution than the quantitative approach, because the biostratigraphic information for many (or even most) stratigraphic levels was inferred from a single occurrence of index tentaculite species within a particular bed. In addition, many levels lack biostratigraphic information (see Chlupáč et al. 1979). The newly gathered quantitative data on tentaculites makes a new proposal of biozonation within the studied interval possible. Comparison of the new and published sedimentological data as well as the application of the new high-resolution biozonation has resulted in a more detailed model of the transgression-regression history across the Daleje Event interval in the Barrandian, and introduced new implications for global Emsian stratigraphy.

\section{Key sections across the Daleje Event interval}

There is many tens of sections across the Daleje Event interval in the Barrandian, but only a few of those were studied with sufficient biostratigraphic resolution for the purposes of the present study (Fig. 1), which is focused on the appearance of the Daleje Event in carbonate-dominated environments. Classical sections such as Švagerka, Praha-Klukovice, Pekárkův mlýn near Solopisky, and Císařská rokle at Srbsko represent successions where the Chýnice Limestone are either undeveloped or where their equivalents form only a few limestone beds. In carbonate-dominated environments, there are only two sections that were well-studied biostratigraphically, Bubovice and Macháčkův lom near Hostim. However, in both of these sections, only the uppermost part of the Chýnice Limestone was studied (see Chlupáč et al. 1979). Additionally, biostratigraphic data from all of the above-mentioned sections had been collected qualitatively (i.e., generally after finding of the first specimen of a biostratigraphically significant tentaculite taxon in a particular bed, the study was finished, and the next bed or stratigraphic interval was sampled). Some intervals were even left without any biostratigraphic datum. However, it should be mentioned that this approach was the standard biostratigraphic method at the time these sections were studied (Chlupáč et al. 1979, Chlupáč \& Lukeš 1999, and partly also Schindler et al. 2003). 

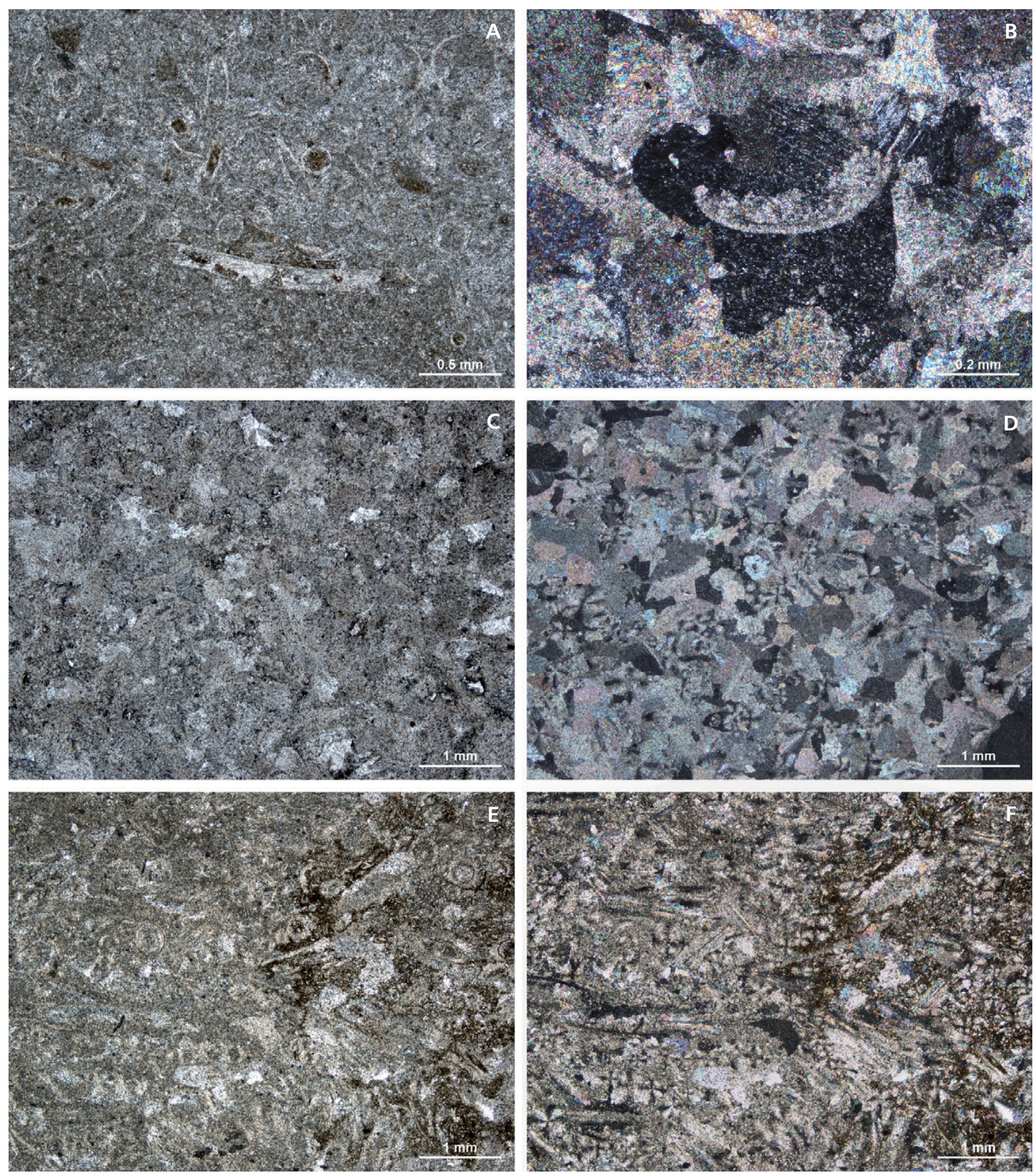

Figure 4. Čeřinka quarry section - thin sections. $\bullet$ A - homogenous tentaculite packstone with calcisiltite matrix and partly bioeroded bioclasts, interval 6, Zlíchov Limestone. • B - recrystallized fragment most likely of an ostracod carapace in polarized light, interval 8, lower part of the Chýnice Limestone. - C, D - completely recrystallized limestones (grainstones) in normal (C) and polarized (D) light (black crosses represent shells of tentaculite shells), interval 8, lower part of Chýnice Limestone. • E, F - tentaculite packstone with highly recrystallized calcisiltite matrix, normal (E) and polarized (F) light, interval 11, upper part of the Chýnice Limestone. 
The section in the Červený lom near the village of Koněprusy, being completely developed in its carbonate facies, was studied in the needed biostratigraphic resolution (Chlupáč et al. 1979), as only some sections of that stratigraphic level were rather densely sampled for conodonts (Klapper 1977, Klapper et al. 1978). Unfortunately, due to the long stratigraphic gap in the Koněprusy area, the sedimentary record at the Červený lom, being the equivalent to the Zlíchovian, is missing.

Before the present study, there was no section in any carbonate-dominated environment of the Barrandian at the Daleje Event interval that had been studied with a sufficient biostratigraphic resolution. To fill this gap in our knowledge, two sections in the NW part of the Barrandian were studied - the Čeřinka hillside and Čeřinka quarry sections. In the following paragraphs, the new sedimentological and biostratigraphic data on these sections are summarized.

\section{New data from carbonate dominated environments}

Both of the newly studied sections, Čeřinka quarry and Čerinka hillside (Fig. 1), are located south of the village of Bubovice (20 km SW of Prague), with a geographic distance of about $400 \mathrm{~m}$. The first section was never studied before. The second section, the Čerinka hillside section, is located to the east of those sections investigated by Chlupáč (1959) and Chlupáč et al. (1979), separated from them by about $20 \mathrm{~m}$ and $100 \mathrm{~m}$, respectively.

\section{Čeřinka quarry section}

This section is located in the NE corner of the Čeřinka quarry (E of the village of Bubovice). This outcrop was created in 2006 by continuing mining in the Čerinka quarry. Since 2008, it has been systematically studied by the senior author of this paper (Ferrová 2010). An approximately $5 \mathrm{~m}$ long section has been studied bed by bed (see Methods). Due to the non-weathered character of the limestones (Figs 2, 3), it was hard to extract all of the macrofossils from the rock. For this reason, the section was primarily studied for the collection of sedimentological and quantitative data on tentaculite biostratigraphic distributions.

\section{Facies development}

The uppermost part of the Zlíchov Limestone, through the entire Chýnice Limestone to the lower part of the calcareous shales (representing transitional layers between the Daleje Shale and the Třebotov Limestone) was studied in detail at the Čeřinka quarry section (Figs 2, 3).
Intervals 1 to 7 of the section, having a total thickness of about $1 \mathrm{~m}$ (Fig. 3), belong to the upper part of the Zlíchov Limestone, which is formed by grey, homogenous, and well-bedded beds of tentaculitid wackestone/packstone with a calcisiltite matrix (Fig. 4A). A typical feature of this succession is the slightly increasing amounts and sizes of the biodetritic content upwards toward the younger beds (to interval 7). Together with the tentaculites, crinoids and ostracods were determined as the most frequent components of the biodetritic materials. The sediment was distinctly bioturbated. Bioerosion of clasts occurs rather rarely. Fragments of corals were found at the top of interval 7 (Radek Labuta, personal communication).

Intervals 8-10, having a total thickness of about $1.2 \mathrm{~m}$, represent the lower portion of the Chýnice Limestone. The transition between the Zlíchov and Chýnice limestones is rapid and rather sharp (Figs 2B-D, 3). The limestone beds of the lower part of the Chýnice Limestone differ from the underlying beds of the Zlíchov Limestone in their lithology. The beds are thicker, and formed by white to light rosy, completely recrystallized limestones (grainstones) (Fig. 4C). The faunal content in thin section is clearly visible, but only determinable using the crossed-nicoles mode (Fig. 4B, D). The preserved small fauna is mainly comprised of tentaculites and ostracods. Pseudosparite forms the main part of these beds.

The upper part of the Chýnice Limestone (Figs 4-6), including intervals 11 to 25 , has a total thickness about $2.3 \mathrm{~m}$. The lithological features of the basal bed (interval 11) differ distinctly from the underlying beds of the lower part of the Chýnice Limestone in their lack of dominant pseudosparite. The basal bed (interval 11, Figs 4E, F and $5 \mathrm{~A}$ ) is formed by rosy calcisiltite tentaculite packstone, with a high degree of recrystallization. Columnals of crinoids are frequent (some of them are bioeroded). Several fragments of corals were also found, but in general, the diversity of macrofossils is rather low. The following three beds (intervals 12-14, Fig. 5B-D) are formed by red tentaculite packstones with calcisiltite matrix (locally recrystallized). Except for tentaculites, other small fauna is mainly represented by fragments of crinoids and less frequently by ostracods, trilobites, bivalves, gastropods, cephalopods, brachiopods as well as rare rugose corals. Cone-in-cone structures of tentaculite shells are abundant. They were reported by Koptíková (2011, pp. 101, 102) also from upper part of the Třebotov Limestone. Bioerosion of the bioclasts of crinoids, trilobites, and other shells occur very commonly, also in analogy to the Třebotov Limestone (Hladil 2004). Abundant stylolites are surrounded with iron oxides.

Yellow to red coloured, tentaculite wackestone with partly recrystallized bioclasts, is characteristic of interval 15 (Fig. 5E). A decrease of the overall diversity and abundance of fossils is evident in comparison with the 

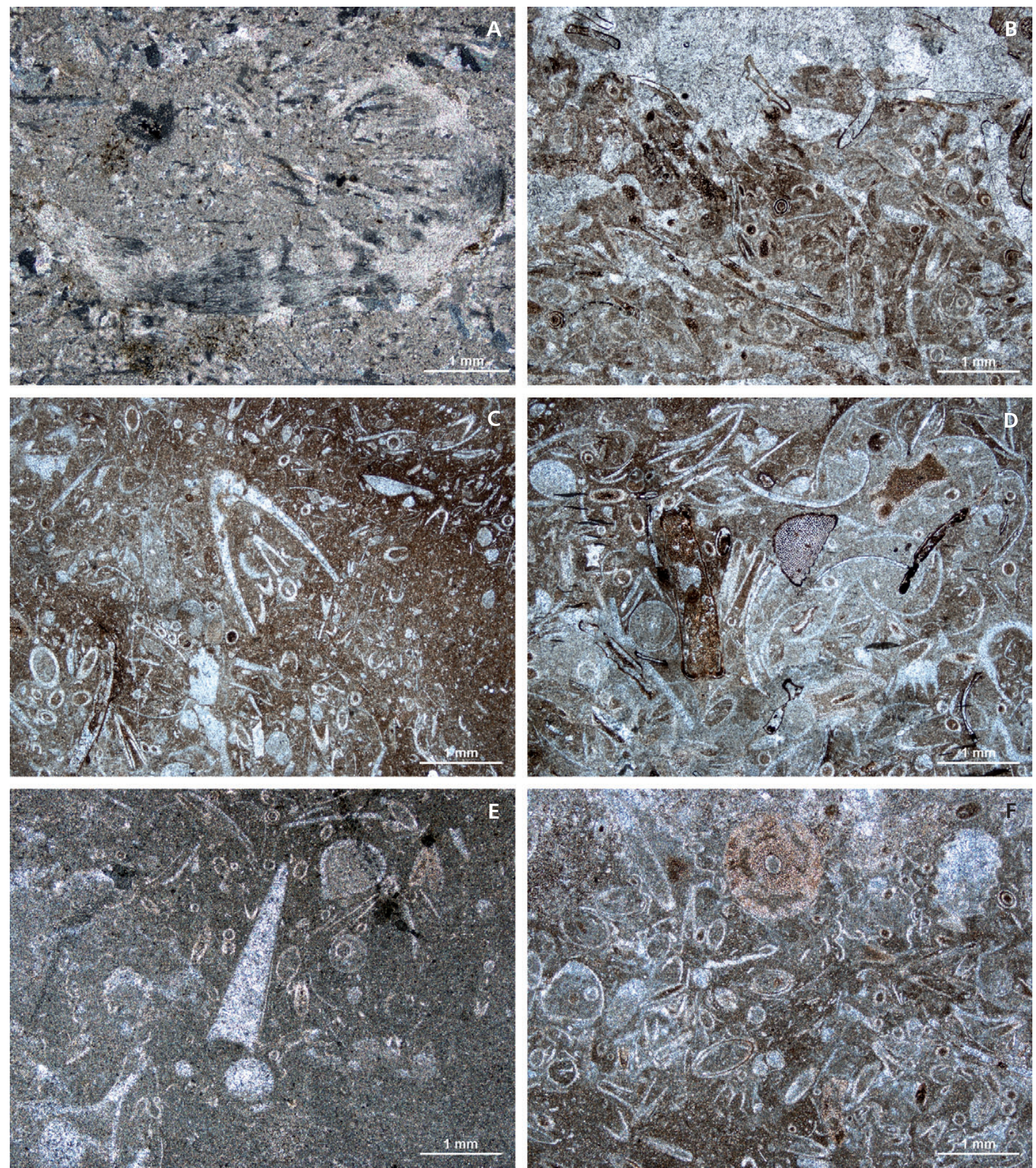

Figure 5. Čeřinka quarry section - thin sections. • A - fragment of coral in polarized light, interval 11, upper part of the Chýnice Limestone. • B - partly recrystallized tentaculite packstone with calcisiltite matrix and "cone-in-cone" structures, interval 13, upper part of the Chýnice Limestone. - C, D - tentaculite packstone with calcisiltite matrix and partly bioeroded fragments of crinoids, ostracods, brachiopods and molluscs, interval 14, upper part of the Chýnice Limestone. $\bullet \mathrm{E}$ - tentaculite wackestone, interval 15, upper part of the Chýnice Limestone. $\bullet \mathrm{F}$ - tentaculite packstone with bioeroded fragment of crinoid, common "cone-in-cone" structures, partly recrystallized, interval 16, upper part of the Chýnice Limestone. 
underlying intervals 12 to 14 . The only exceptions are cephalopod fragments, which are more abundant than in the other intervals. Beds of tentaculite packstones, separated from one another by very thin 2 to $5 \mathrm{~mm}$ thick intercalations of barren shales, represent intervals 16 to 17 (Fig. 5F). Fragments of crinoids, ostracods, trilobites, and bivalves represent the greater part of the bioclasts. Cone-in-cone structures are common. Interval 18 is formed by a $3 \mathrm{~cm}$ thick layer of grey, strongly calcareous, soft shale. It contains numerous shells of poorly-determinable tentaculites, brachiopods, and ostracods.

Intercalations of homogeneous, tentaculite wackestone/packstone and calcareous shales are typical features of intervals 19 to 22 (Fig. 6A). Except for the tentaculites, other fossils are rather rare. The limestones are partly recrystallized. Cone-in-cone structures are present. Interval 23 is formed by a distinct, $20 \mathrm{~cm}$ thick bed of dark red packstone (Fig. 6B). The fossil assemblage of this limestone bed is diversified - including abundant fragments of tentaculites, ostracods, trilobites, and crinoids. Rarely, hyolith shells and fragments of crustaceans were also found, as well as a bryozoan zoecium in life-like positions (attached upon a clast; Fig. 6C, D). Bioerosion of trilobite and crinoid fragments are common, as well as cone-incone structures. The sediment was bioturbated. One interesting point is that the diversified assemblage, seen in the thin sections, was not possible to extract by hammering (by this method, only a few carapaces of ostracods were acquired). The limestone beds of interval 24 and 25 represent the end of sedimentation of the Chýnice Limestone. A typical feature of these highly recrystallized tentaculite wackestone/packstone beds, intercalated with thin layers of calcareous shale, is the low abundance and overall diversity of the macrofossils.

The final part of the section (intervals 26 to 29 , Fig. 6F) consists of compacted calcareous shales, with subordinate amounts of red micritic limestones beds and lenses, forming the transition between the Daleje Shale and the Třebotov Limestone (compare with Chlupáč et al. 1979). Both limestones and shales contain tentaculite fauna.

\section{Carbon isotopes}

Thirty five samples collected at the Čeřinka quarry section for isotope analyses of the carbonate carbon include an interval from the upper Zlíchov Limestone to the top of the Chýnice Limestone (Fig. 7). Measured values (Table 1) from the upper Zlíchov Limestone and the lower part of the Chýnice Limestone (intervals 1 to 10) have a rather uniform development. However, the value from interval 11 (the first bed of the upper part of the Chýnice Limestone) and from the stratigraphically younger beds are suddenly and distinctly lower and reach even negative values (Figs 7, 8).

\section{Notes on overall biodiversity}

Investigation of the Čeřinka quarry section mainly focused on the study of carbonate petrology and quantitative tentaculite biostratigraphy. As a side product of the laboratory processing and separation of all determinable tentaculite shells, a rather large collection of other faunal elements was produced. The fauna from the Čerinka quarry section includes trilobites, ostracods, bivalves, gastropods, cephalopods, brachiopods, anthozoans, rostroconchs, and hyolithes; aside from the more than 1250 determinable shells of tentaculites. In total, this fauna represents (without tentaculites) more than 50 different taxa, and will be further evaluated in the coming years.

\section{Čeřinka hillside}

The Čeřinka hillside section is situated SE from the village of Bubovice, and has been a well-known palaeontological locality of the Chýnice Limestone for more than 50 years. A list of fossils from this locality (often called Bubovice) was published by Chlupáč (1957, 1959), Chlupáč et al. (1979, 1998), and Havlíček \& Vaněk (1996). Newly described taxa from the Čeřinka hillside section include inarticulate brachiopods, trilobites, and gastropods (Vaněk 1998; Frýda 2001; Frýda et al. 2008b, 2009; Budil et al. 2009; and Mergl \& Ferrová 2009). During the years 2006 to 2010 , this section was intensively studied by Lenka Ferrová. The section was exposed in an approximately $25 \mathrm{~m}$ long trench, which included the upper part of the Zlíchov Limestone, the entire Chýnice Limestone, and transitional layers between the Daleje Shale and the Třebotov Limestone. The dip of the limestone beds in the entire studied section was uniformly about $30^{\circ}$ to the NW.

\section{Facies development}

The first two intervals $(1,2)$ have a total thickness of about $80 \mathrm{~cm}$ (Fig. 3) and represent the upper part of the Zlíchov Limestone. It consists here of light grey, homogeneous, and well-bedded beds of tentaculite wackestone/ packstone without cherts, but with a calcisiltite matrix bearing a poor macrofaunal content (mostly fragments of trilobites and brachiopods; Fig. 8A). Fragments of crinoids, ostracods, and tiny gastropod shells were also observed as a subordinate faunal component. The sediment in these intervals was distinctly bioturbated. Indefinite edges between burrows and the enclosing sediment suggests that bioturbation had already started in the semi-lithified sediment. There is an increase from the base of interval 1 to the top of interval 2 in both the abundance and diversity of the bioclasts, as well as in the amounts of broken shells. 

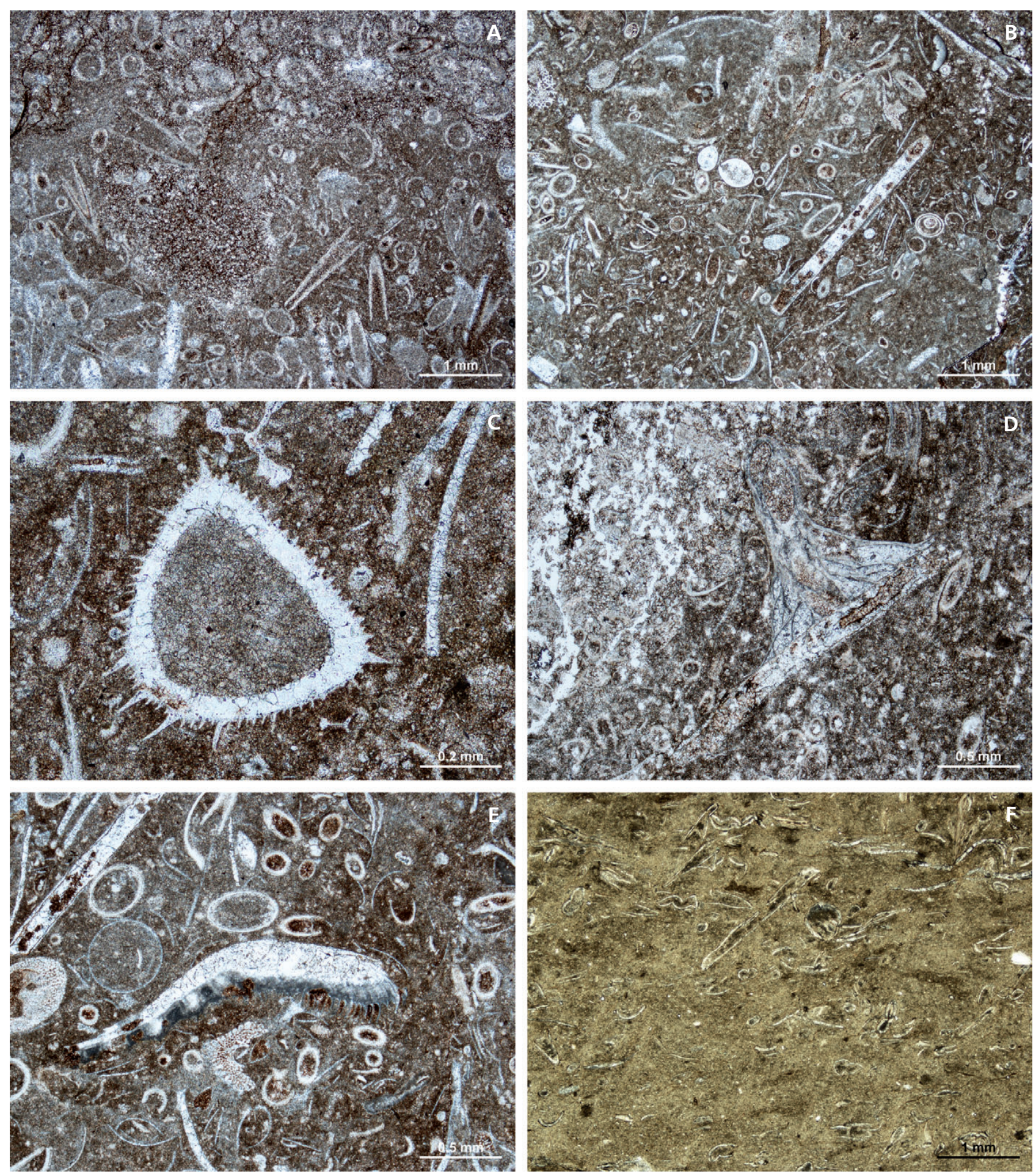

Figure 6. Čeřinka quarry section - thin sections. • A - partly recrystallized tentaculite packstone, interval 19, upper part of the Chýnice Limestone. - B-E - thin sections from interval 23, upper part of the Chýnice Limestone. B - packstone with diversified and partly bioeroded bioclasts of tentaculites and other molluscs, crinoids, and ostracods; C - cross section of hyolithid (?) shell; D - small bryozoan zoecium attached on bioclast; E - well-preserved fragment of crustacean carapace. $\bullet \mathrm{F}$ - calcareous tentaculite shale, lower part of the Daleje Shale. 
Table 1. Isotope composition of carbonate carbon from the Čerinka quarry limestone samples. Sampling covers much wider stratigraphic interval of the Ceřinka quarry section than biostratigraphic sampling. Table shows a position of each sample relative to stratigraphic intervals.

\begin{tabular}{|c|c|c|c|}
\hline Scale $(\mathrm{cm})$ & Interval & $\delta^{13} \mathrm{C}(\% \circ \mathrm{PDB})$ & $\delta^{18} \mathrm{O}(\% \circ \mathrm{PDB})$ \\
\hline 0 & & 0.34 & -3.29 \\
\hline 18 & & 0.64 & -3.03 \\
\hline 53 & & 0.76 & -2.64 \\
\hline 76 & & 0.62 & -2.86 \\
\hline 93 & & 0.44 & -2.97 \\
\hline 107 & & 0.45 & -2.96 \\
\hline 107 & & 0.72 & -2.81 \\
\hline 129 & & 0.69 & -2.68 \\
\hline 147 & & 0.70 & -2.71 \\
\hline 169 & & 0.75 & -2.73 \\
\hline 187 & & 0.87 & -2.15 \\
\hline 204 & & 0.73 & -2.53 \\
\hline 209 & 1 & 0.70 & -3.28 \\
\hline 222 & 2 & 0.71 & -2.32 \\
\hline 240 & 3 & 0.29 & -2.95 \\
\hline 255 & 3 & 0.50 & -2.46 \\
\hline 265 & 4 & 0.60 & -2.28 \\
\hline 275 & 4 & 0.71 & -2.10 \\
\hline 295 & 5 & 0.71 & -2.58 \\
\hline 315 & 6 & 0.75 & -2.63 \\
\hline 315 & 6 & 0.78 & -2.67 \\
\hline 335 & 7 & 0.71 & -2.63 \\
\hline 355 & 8 & 0.65 & -2.57 \\
\hline 375 & 8 & 0.58 & -2.76 \\
\hline 395 & 9 & 0.50 & -2.50 \\
\hline 423 & 9 & 0.44 & -2.78 \\
\hline 451 & 10 & 0.61 & -2.50 \\
\hline 451 & 10 & 0.66 & -2.42 \\
\hline 474 & 11 & -0.24 & -2.81 \\
\hline 502 & 13 & -0.64 & -3.35 \\
\hline 524 & 14 & -0.18 & -3.23 \\
\hline 547 & 15 & -0.06 & -3.85 \\
\hline 569 & 16 & -0.19 & -4.15 \\
\hline
\end{tabular}

Intervals 3 to 14 , with a total thickness of $2.5 \mathrm{~m}$, represent the lower part of the Chýnice Limestone (Figs 8B-F, 9A, B). The transition between the Zlíchov and Chýnice limestone is rather sharp. Sedimentation of the Chýnice Limestone begins with an approximately $5 \mathrm{~cm}$ thick layer of weathered, totally recrystallized grainstone (size of the calcite grains about 1 to $2 \mathrm{~mm}$ ). Because of this, a determination of the primary sedimentological features of this interval is impossible. The following beds are formed by white to light rosy neomorphized limestones (grainstones) bearing fragments of ostracods, tentaculites, small trilobites, brachiopods, and locally abundant spicules (Fig. 8B-D). Sometimes, the bioclasts are micritized. Microsparite is often concentrated in the fillings of convex shells and the shells of tentaculites. Pseudosparite forms approximately $40 \%$ of the rock volume. A typical feature of the following intervals ( 5 and 6 ) is a gradual upwards increase in the amount of crinoidal fragments.

The lower part of the Chýnice Limestone (intervals 7 to 14 ; Fig. 3) show a gradual change from rosy unsorted floatstones with calcisiltite matrix, through poorly washed crinoidal packstones with pelletoids, to rosy crinoidal grainstones in the upper part (Figs 8E, F, 9A, B). Apart from crinoidal detritus, numerous fragments of different trilobites, corals, tentaculites, and ostracods were documented. Less frequent faunal elements include gastropods, cephalopods, rostroconchids, and bivalves. Traces of bioerosion are rare within all of these intervals (7-14).

The upper part of the Chýnice Limestone is formed by coarsely bedded limestone beds of a grey to red-brown colour. Intervals 15 to 18 represent unsorted floatstones with umbrella structures and pluricolumnals of crinoids to coral bindstones (Fig. 9C-F). The most abundant fauna are crinoids, trilobites, corals, tentaculites, and brachiopods.

The following succession also contains limestone beds formed by in situ benthic organisms (mainly corals). The top of the Chýnice Limestone and its boundary with the calcareous shale layers, forming the transition between the Daleje Shale and the Třebotov Limestone, is quite fast, yet gradual. This interval was studied by Chlupáč et al. (1979) at a very close section (named as Bubovice). Generally, the amount of fine grained carbonate particles, as well as of fine siliciclastic materials, gradually increases as the biodetritic component decreases (Chlupáč et al. 1979, and in our data). The uppermost part of the section has not yet been studied in detail, and will be one of the goals of the ongoing project.

\section{Notes on overall biodiversity}

Investigation of the Čeřinka hillside section mainly focused on the palaeoecology of the taxa occurring in the Chýnice Limestone. Since 2008, systematic research of this section was performed by Ferrová (2010). More than 2,100 fossil specimens belonging to 84 species were collected in the lower part of the Chýnice Limestone (intervals 7 to 14 with a total thickness of about $2.5 \mathrm{~m}$ ). The upper part of the Chýnice Limestone, with an even higher diversity, is currently studied by the senior author. Publications evaluating the entire fauna are in preparation; three short papers based on these newly collected materials have already been published (Frýda et al. 2008b, 2009; Mergl \& Ferrová 2009). 


\section{Tentaculite biostratigraphy}

The stratigraphic distributions of all species of tentaculites (dacryoconarid, as well as true tentaculites) were examined at both newly studied sections, the Čeřinka hillside and Čeřinka quarry. Quantitative data, representing more than 1250 determined specimens are plotted in Figs 10 and 11 together with the results of rarefaction analyses (Fig. 12), which verified a good sampling density at the Čeřinka quarry section. Fourteen tentaculite species were documented at both of the studied sections. In addition, several important biostratigraphic observations have been made. Irrefutable co-occurrences of $N$. barrandei and $N$. elegans (Figs 3,11) as well as irrefutable co-occurrences of $N$. elegans and $N$. cancellata have been discovered.

Careful evaluation of more than 800 tentaculite shells belonging to the species $N$. barrandei, $N$. elegans, and $N$. cancellata reveals numerous occurrences of transitional forms between $N$. elegans and $N$. cancellata (see discussion below), but not between $N$. barrandei and N. elegans.

In the following section, the basic data on all of the tentaculites found are summarized together with a list of all their occurrences in the Barrandian area, based on published papers as well as on the unpublished data of Pavel Lukeš. The terms Zlíchovian and Dalejan are used in the following taxonomic portion in the traditional sense (i.e., the Dalejan starts with the first occurrence of Nowakia cancellata). The character "+" means that the mentioned taxa occur together.

\section{Tentaculitids found at the Čeřinka sections}

Order Tentaculitoidea Lyashenko, 1957

Family Tentaculitidae Walcott, 1886

\section{Genus Dicricoconus Fisher, 1962 \\ (= Heteroctenus Lyashenko, 1955)}

\section{Dicricoconus sp.}

Čeřinka sections. - 7 incomplete shells from the Čeřinka quarry section (upper part of Chýnice Limestone - layers with $N$. elegans and N. elegans $+N$. cancellata).

Other occurrences in the Barrandian. - Voskop quarry (Koněprusy area): lowermost part of the Suchomasty Limestone (the filling of Neptunian dykes) without dating by index dacryoconarid tentaculites.

Stratigraphic range. - Uppermost Zlíchovian-lower Dalejan, Emsian.

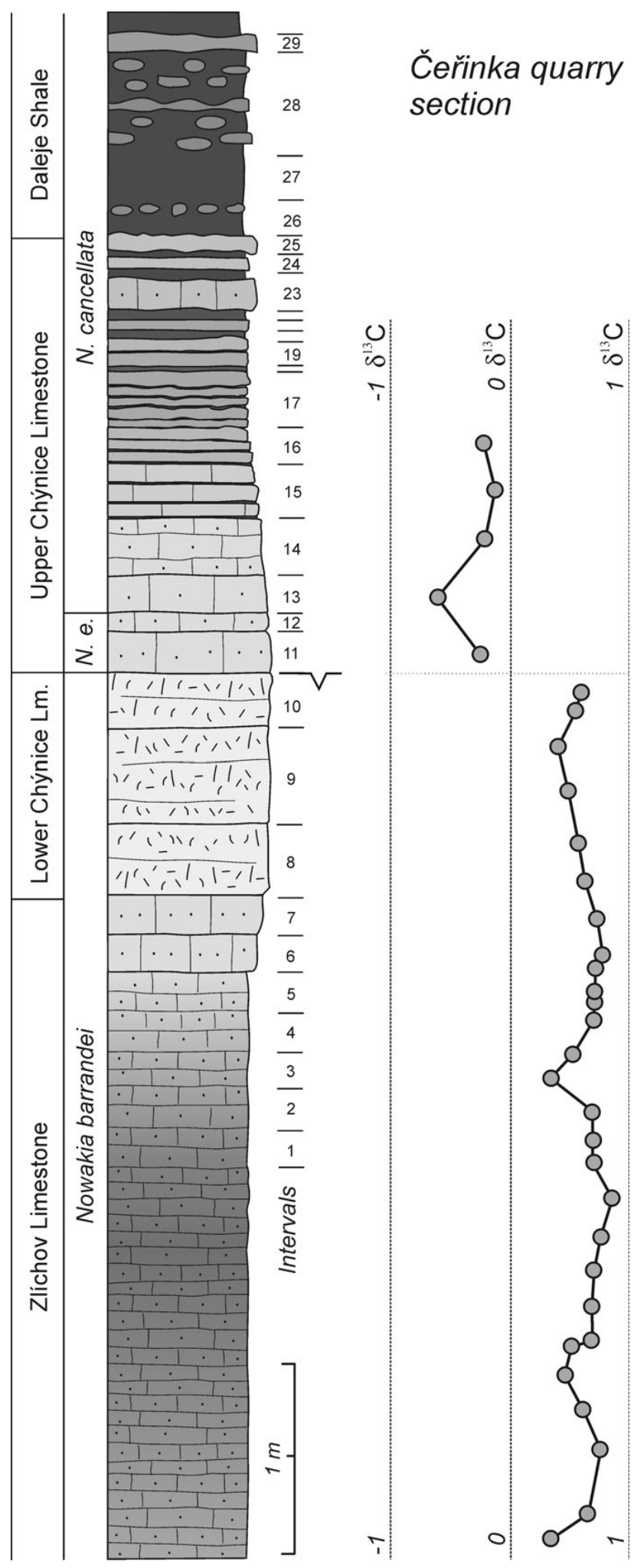

Figure 7. Čeřinka quarry section showing isotope composition of carbonate carbon from individual stratigraphic intervals. Note the sudden change in $\delta^{13} \mathrm{C}$ values at the sequence boundary (boundary of intervals 10 and 11). 
Remarks. - Incomplete shells 2 to $4 \mathrm{~mm}$ long without proximal part do not allow precise species determination. Nevertheless a thick body wall with fine dense rings and conspicuous protuberant mounds place these shells into genus Dicricoconus.

Order Homoctenida Bouček, 1964

Family Homoctenidae Lyashenko, 1955

\section{Genus Homoctenus Lyashenko, 1955}

\section{Homoctenus hanusi (Bouček, 1964)}

Holotype. - Specimen figured by Bouček (1964) on pl. 40, fig. 1; Coll. NM L 6287a.

Type locality. - Praha-Hlubočepy, outcrop near the upper viaduct.

Type horizon. - Daleje Shale with N. cancellata (upper Emsian).

Čerinka sections. - Tens of shells, all preserved without the proximal part, from the Čeřinka quarry section (upper part of the Zlíchov Limestone and the Chýnice Limestone - almost continuous occurrence from layers with $N$. barrande $i$ to those with $N$. cancellata) and from the Čerinka hillside section (Chýnice Limestone - layers with $N$. barrandei and $N$. barrandei $+N$. elegans $)$.

Other occurrences in the Barrandian. - Švagerka section (bed No. 26, upper part of Zlíchov Limestone with N. barrandei); Klukovice section (lower part of the Chýnice Limestone with $N$. barrandei); Pekárkův mlýn section (upper part of Zlíchov Limestone to lower part of Daleje Shale - layers with N. barrandei and N. elegans); Macháčkův lom near Hostim (lowermost part of the Třebotov Limestone - dating by index dacryoconarid species was not available). Bouček (1964) noted several additional occurrences: Karlštejn - V Hlubokém Valley (Daleje Shale); Holyně (Třebotov Limestone); Dolní Roblín (Eifelian Choteč Limestone).

Stratigraphic range. - Upper Zlíchovian-Dalejan, Emsian, and ?Eifelian (Bouček 1964).

Remarks. - Detailed description of this species is given by Bouček (1964, pp. 144-146).

Subclass Dacryoconarida Fisher, 1962

Order Nowakiida Lyashenko, 1955

\section{Genus Nowakia Gürich, 1896}

Nowakia (Nowakia) barrandei Bouček \& Prantl, 1959 Figures 13D-F, 14A-C, K-O, 15B, C

Holotype. - Specimen figured by Bouček (1964) on pl. 8, fig. 2, Coll. NM L6185, National Museum, Prague.

Type locality. - Choteč (Barrandian area, Czech Republic).

Type horizon. - Upper layers of the Zlíchov Limestone, Zlíchovian (lower Emsian, Devonian).

Čřrinka sections. - Tens of very well preserved shells from the Čerinka quarry section (uppermost part of the Zlíchov Limestone and lower part of Chýnice Limestone) and from the Čeřinka hillside section (lower part of Chýnice Limestone and in basal beds of upper part of Chýnice Limestone together with $N$. elegans).

Other occurrences in the Barrandian. - Švagerka section (uppermost part of the Zlíchov Limestone and lowermost part of the Daleje Shale - documented co-occurrence with N. elegans); Pekárkův mlýn section (upper part of the Zlíchov Limestone); Klukovice section (Chýnice Limestone); Císařská rokle section (upper part of the Zlíchov Limestone and the Chýnice Limestone); Lukeš (1977) noted additional occurrences: Chýnice "Ve mlýnci"; Praha-Holyně; Kominická rokle near Choteč.

Stratigraphic range. - Upper Zlíchovian (lower Emsian, Devonian).

Remarks. - Detailed description of was given by Bouček (1964, pp. 74-77), Lardeux (1969, pp. 96-99), Lukeš (1977, p. 20) and Alberti (1993, pp. 33, 34).

Nowakia (Nowakia) elegans (Barrande, 1867)

Figures 13A-C, 14D-J, 15A,D

Holotype. - Specimen figured by Barrande (1867) on pl. 14, figs 20-24 and by Bouček (1964) on pl. 11, fig. 1, Coll. NM L6206; National Museum, Prague.

Type locality. - Vávrův mlýn in the Radotín Valley (= "Wawrowitz"), Prague, Czech Republic.

Type horizon. - The uppermost layers of the Zlíchov Limestone and lowermost part of Daleje Shale, uppermost Zlíchovian (Emsian, Devonian).

Čr řinka sections. - Tens of very well preserved shells from the Čeřinka quarry section (upper part of the Chýnice 

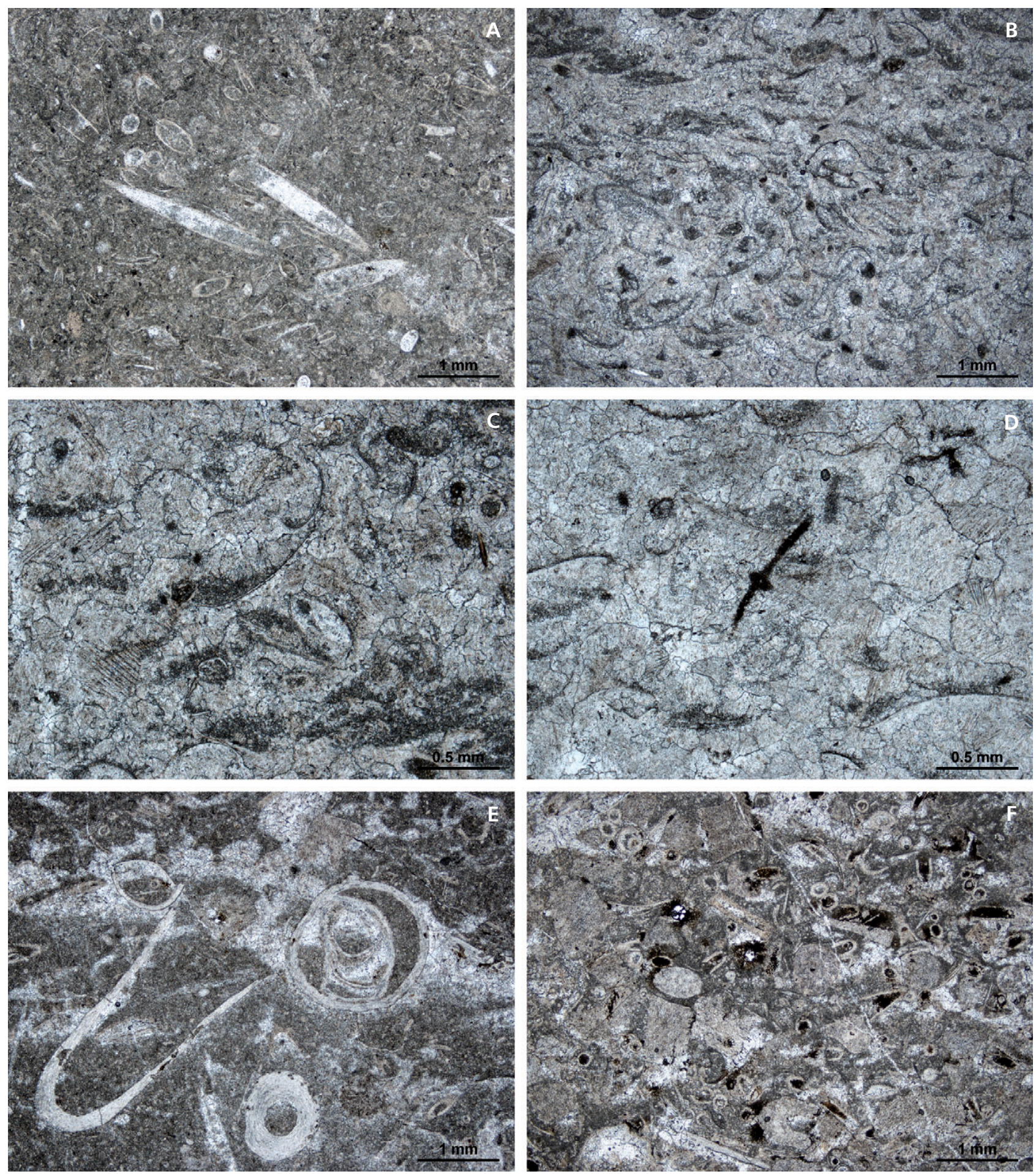

Figure 8. Čerinka hillside section - thin sections. $-A$ - homogenous tentaculite packstone with calcisiltite matrix, interval 1 , uppermost part of the Zlíchov Limestone. • B-D - interval 4, lower part of the Chýnice Limestone. B - recrystallized limestone (grainstone) containing of tentaculite shells and fragments of ostracods partly filled with microsparite (dark coloured); $\mathrm{C}$ - detail view of partly micritized ostracod carapace filled with microsparite (middle of the figure); D - detail view of black coloured spicule. $\bullet \mathrm{E}$ - floatstone with fragments of corals, crinoids, ostracods, brachiopods, tentaculites and other molluscs, interval 7 , lower part of the Chýnice Limestone. $\bullet \mathrm{F}$ - crinoidal-tentaculite packstone, shells are partly recycled (fillings of tentaculite shells are different from the matrix), interval 8, lower part of the Chýnice Limestone. 
Limestone also together with $N$. cancellata) and from the Čerinka hillside section (upper part of the Chýnice Limestone together with $N$. barrandei).

Other occurrences in the Barrandian. - Švagerka section (uppermost part of the Zlíchov Limestone and lower part of the Daleje Shale also together with N. barrandei); Klukovice section (uppermost part of the Chýnice Limestone and lower part of the Daleje Shale); Pekárkův mlýn section (uppermost part of the Zlíchov Limestone and lower part of the Daleje Shale); Císařská rokle section (Chýnice Limestone); Červený lom (lower part of the Suchomasty Limestone). Lukeš (1977) noted additional occurrences: Praha-Holyně and Kominická rokle.

Stratigraphic range. - Uppermost Zlíchovian and lowermost Dalejan (Emsian, Devonian).

Remarks. - Detailed description is given by Lukeš (1976, pp. 20-23), Salah (1976, pp. 29-39) and by Alberti (1993, pp. 37,38$)$.

\section{Nowakia (Nowakia) elegans (Barrande, 1867) $\rightarrow$ Nowakia (Nowakia) cancellata (Richter, 1854)}

Čerinka sections. - Tens of well-preserved shells from the Čeřinka quarry section (upper part of Chýnice Limestone together with $N$. elegans and N. cancellata).

Remarks. - Transitional forms between N. elegans and N. cancellata (in sense of Lukeš 1977) were first recognized by Alberti (1993), who figured them on table 17 (figs 5-11). Material newly collected at the Čeřinka hillside section revealed several different types of "transitional" forms. The most noticeable form has proximal parts of juvenile shell with a "cancellata-like" shape and ornamentation. However, the adult part of the shell bears an "elegans-like" shape and ornamentation. Large and well-preserved new material needs further detailed study using numerical methods.

Stratigraphic range. - Uppermost Zlíchovian to lowermost Dalejan (Emsian, Devonian).

Other occurrences in the Barrandian. - Pekárkův mlýn section (lower part of the Daleje Shale together with N. elegans); Karlštejn - V Hlubokém Valley (lower part of the Daleje Shale together with $N$. cancellata); Císařská rokle section (Chýnice Limestone together with N. elegans).

\section{Nowakia (Nowakia) cancellata (Richter, 1854)}

Holotype. - Specimen figured by Richter (1854) on pl. 3, figs $10-13$.
Type locality. - East Thuringian Highland (original locality unknown, Germany).

Type horizon. - "Schiefer der Tentaculitenschichten" (original designation of R. Richter), lower Dalejan, upper Emsian (Devonian).

Čeřinka sections. - Hundreds of complete shells preserved in limestones as well as in shales from the Čeřinka quarry section (upper part of the Chýnice Limestone and lower part of transitional layers between the Daleje Shale and the Třebotov Limestone together with $N$. elegans) and from the Čeřinka hillside section (Daleje Shale).

Other occurrences in the Barrandian. - Klukovice section (Daleje Shale - $9 \mathrm{~m}$ above the boundary with the Chýnice Limestone); Pekárkův mlýn section (Daleje Shale $-12 \mathrm{~m}$ above the boundary with the Zlíchov Limestone); Karlštejn (lower part of the Daleje Shale); Císařská rokle section (lower and middle part of the Daleje Shale); Macháčkův lom near Hostim (lowermost part of the Třebotov Limestone in about $1 \mathrm{~m}$ thick interval); Červený lom (lower part of the Suchomasty Limestone). Lukeš (1977) noted additional occurrences: Chýnice "Ve mlýnci” and Kominická rokle.

Stratigraphic range. - Lower Dalejan (upper Emsian, Devonian).

Remarks. - Detailed description is given in Salah (1976, pp. 40-48, table 3, figs 1-10), Lukeš (1977, pp. 23-24, table 1, fig. 3, table 5, figs 1-7, table 7, figs 1-3), Alberti (1993, pp. 335-336, table 13, fig. 13, table 19, figs $1-16$, text-fig. 9).

\section{Genus Viriatellina Bouček, 1964}

\section{Viriatellina hercynica Bouček, 1964}

Holotype. - Specimen figured by Bouček (1964) on pl. 17, fig. 6, Coll. NM S1830; National Museum, Prague.

Type locality. - Zorge, Harz (Germany).

Type horizon. - Upper layers of the "Tentaculitenknollenkalk"; Dalejan (upper Emsian, Devonian).

Čerinka sections. - Tens of very well preserved shells from the Čeřinka quarry section (upper part of the Zlíchov Limestone and Chýnice Limestone together with N. barrandei, $N$. elegans and $N$. cancellata) and from the Čerinka hillside section (Chýnice Limestone - in layers with $N$. barrandei and $N$. barrandei $+N$. elegans). 

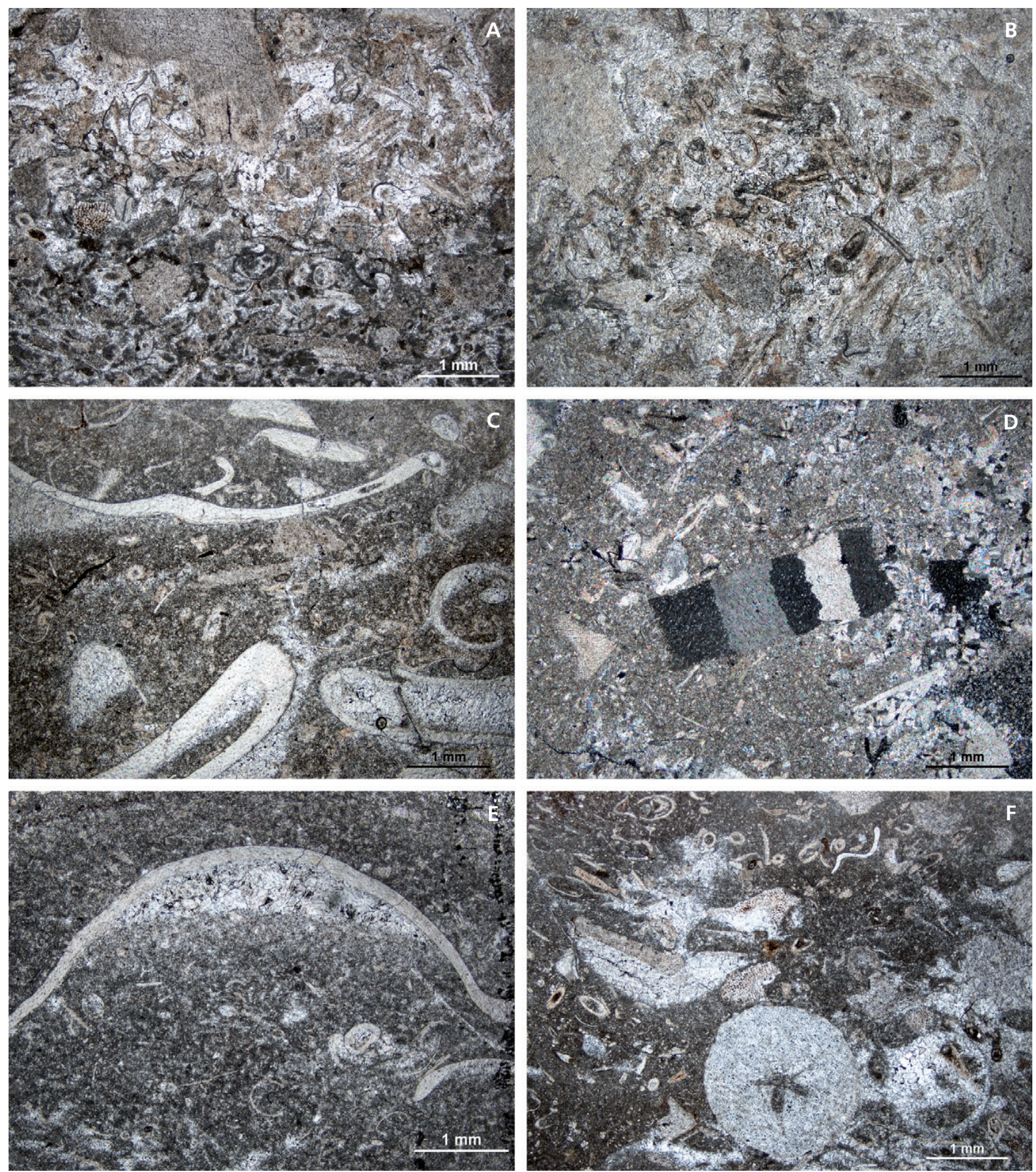

Figure 9. Čeřinka hillside section - thin sections. • A - recrystallized limestone with micritic pelletoids and altered (micritized) and non-altered shells (lower part of view) and crinoidal grainstone (upper part of view) separated by stylolitic boundary, interval 8, lower part of the Chýnice Limestone. - B - crinoidal grainstone, interval 13 , lower part of the Chýnice Limestone. $\bullet \mathrm{C}$ - unsorted floatstone with diversified bioclasts. $\bullet \mathrm{D}$ - pluricolumnal of crinoid, E - umbrella structure (fragment of trilobite shell). C-E - interval 15, upper part of the Chýnice Limestone. $\bullet \mathrm{F}$ - crinoidal unsorted floatstone with fragments of tentaculites, corals and other fossils, interval 17, upper part of the Chýnice Limestone. 


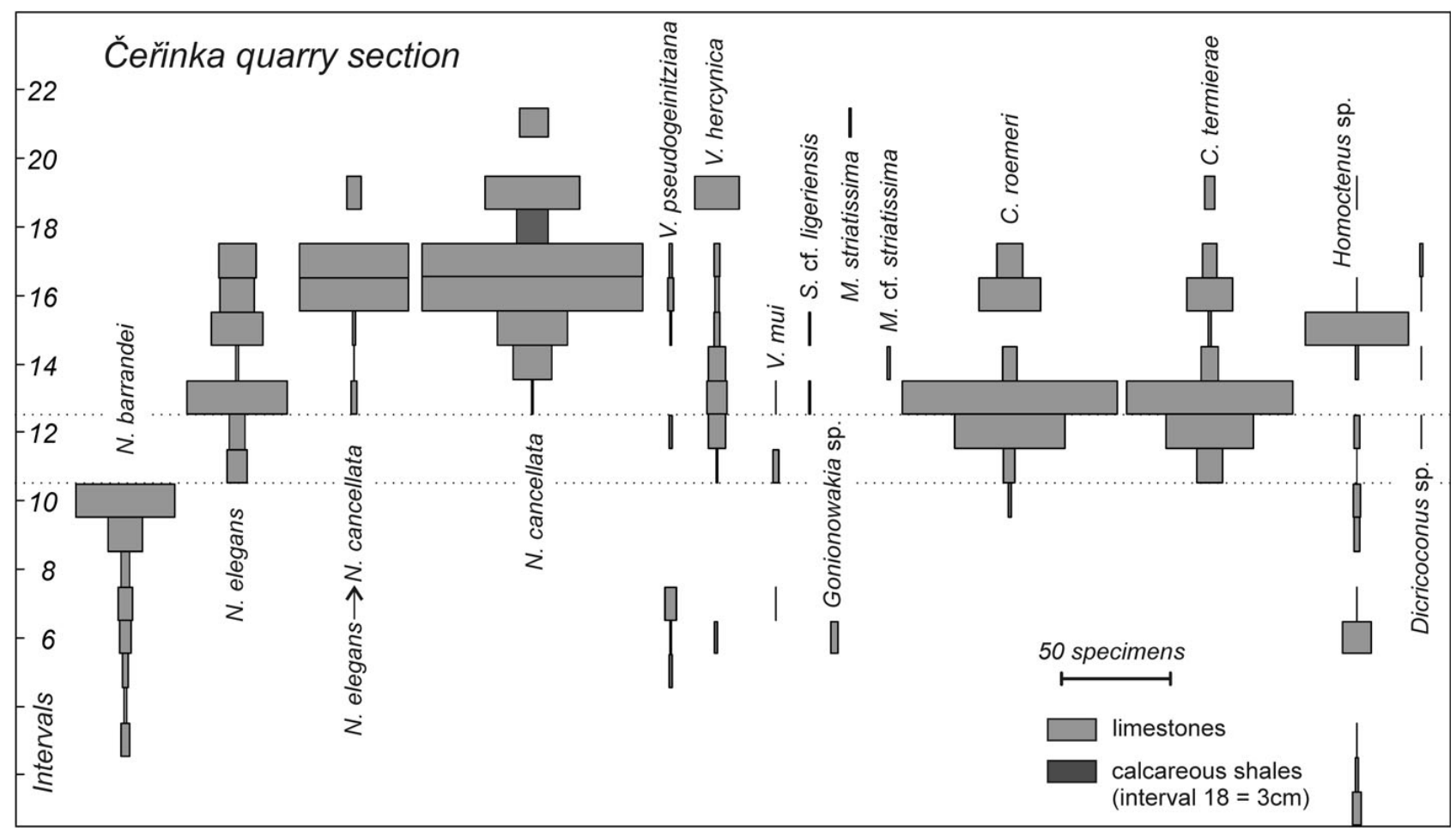

Figure 10. Čeřinka quarry section - quantitative data on the stratigraphic distribution of tentaculites.

Other occurrences in the Barrandian. - Švagerka section (upper part of the Zlíchov Limestone to lower part of the Daleje Shale in layers with $N$. barrandei and $N$. barrandei $+N$. elegans); Klukovice section (Chýnice Limestone with $N$. barrandei); Pekárkův mlýn section (upper part of the Zlíchov Limestone and lowermost layer of the Daleje Shale - layers with $N$. barrandei and N. elegans); Karlštejn - V Hlubokém Valley (upper part of the Zlíchov Limestone); Císařská rokle section (upper part of the Zlíchov Limestone and the Chýnice Limestone with $N$. barrandei and $N$. elegans).

Stratigraphic range. - Upper Zlíchovian to lower Dalejan (Emsian, Devonian).

Remarks. - Detailed descriptions in Bouček (1964, pp. 95 , 96, table XVII, figs 3-7), Lardeux (1969, pp. 126-128, figs 95-96). Alberti (1998) introduced new several taxa closely resembling $V$. hercynica.

\section{Viriatellina pseudogeinitziana Bouček, 1964}

Holotype. - Specimen figured by Bouček (1964) on pl. 18, fig. 1; Coll. NM L6212, National Museum, Prague.

Type locality. - Choteč (Barrandian, Czech Republic).
Type horizon. - Uppermost layers of the Zlíchov Limestone; uppermost Zlíchovian (lower Emsian, Devonian).

Čerinka sections. - About 26 shells from the Čeřinka quarry section (upper part of the Zlíchov Limestone and the Chýnice Limestone with $N$. barrandei, N. elegans + $N$. cancellata) and from the Čerrinka hillside section (Chýnice Limestone with $N$. barrandei and $N$. barrandei + N. elegans).

Other occurrences in the Barrandian. - Švagerka section (upper part of the Zlíchov Limestone with N. barrandei); Klukovice section (Chýnice Limestone with $N$. barrandei); Pekárkův mlýn section (upper part of the Zlíchov Limestone with $N$. barrandei); Císařská rokle section (upper part of the Zlíchov Limestone with $N$. barrandei). Lukeš (1977) noted also Kominická rokle.

Stratigraphic range. - Upper Zlíchovian to lower Dalejan (Emsian, Devonian).

Remarks. - Detailed descriptions is given by Bouček (1964, pp. 96-99) and Lardeux (1969, pp. 134-136). $V$. pseudogeinitziana occurs commonly together with $V$. hercynica but former species has bigger and more robust shell with higher number of longitudinal ribs than $V$. hercynica. V. pseudogeinitziana has in comparison with $N$. barrandei just undulated surface of the shell. 


\section{Viriatellina mui Alberti, 1993}

Holotype. - Specimen figured by Alberti (1993) on pl. 43, fig. 2, Coll. SMF 48696.

Type locality. - Gara Mdouard SW Erfoud (Tafilalt, Morocco).

Type horizon. - Biodetritic limestone with Nowakia barrandei (lower Emsian, Devonian).

Čerinka sections. - About ten mostly incomplete but wellpreserved shells from the Čeřinka quarry section (uppermost part of the Zlíchov Limestone to upper part of the Chýnice Limestone with $N$. barrandei to $N$. elegans $+N$. cancellata).

Other occurrences in the Barrandian. - Švagerka section (upper part of the Zlíchov Limestone with $N$. barrande + $N$. elegans); Klukovice section (Chýnice Limestone, bed no. 39 with $N$. barrandei).

Stratigraphic range. - Upper Zlíchovian (lower Emsian, Devonian).

Remarks. - Detailed description is given by Alberti (1993, pp. 72, 73). Morphological characters of $V$. mui resemble those in Stylionowakia ligeriensis Lardeux, 1969. The latter species occurs also in layers with $N$. barrandei. Shells of $V$. mui are longer, more robust and bearing transversal mounds in middle and apical part of the shell. In S. ligeriensis transversal mounds occur in apertural part. However it is difficult to determination incomplete shells.

\section{Genus Stylionowakia Lardeux, 1969}

\section{Stylionowakia ligeriensis Lardeux, 1969}

Holotype. - Specimen figured by Lardeux (1969) on pl. 47, fig. 1; Institut de Paléontologie du Muséum d'Historie naturelle de Paris.

Type locality. - La Grange near Chalonnes (Armorican Massif).

Type horizon. - La Grange Limestone (lower Emsian, Devonian).

Remarks. - See remarks of V. mui.

Čerinka sections. - Several incomplete but well preserved shells from the Črrinka hillside section (lower part of the Chýnice Limestone with N. barrandei).

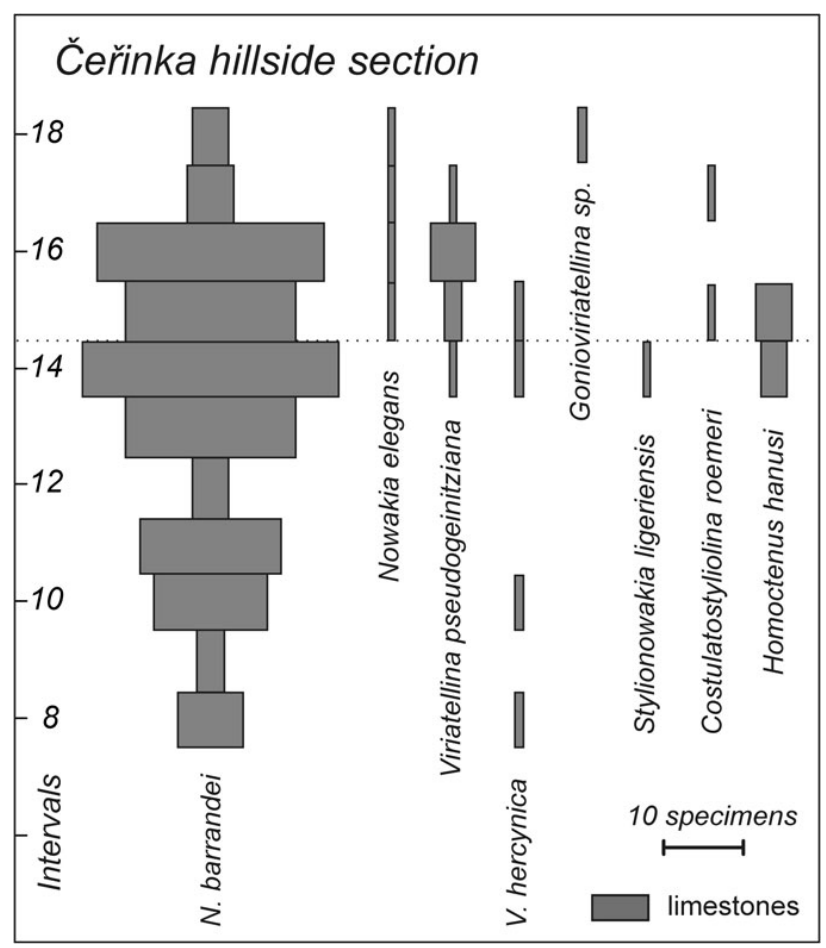

Figure 11. Čeřinka hillside section - quantitative data on the stratigraphic distribution of tentaculites.

Other occurrences in the Barrandian. - Klukovice section (Chýnice Limestone with $N$. barrandei); Pekárkův mlýn section (upper part of the Zlíchov Limestone, bed No. 16 with $N$. barrandei).

Stratigraphic range. - Upper Zlíchovian (lower Emsian, Devonian).

\section{Genus Metastyliolina Bouček \& Prantl, 1961}

\section{Metastyliolina striatissima Bouček \& Prantl, 1961}

Holotype. - Specimen figured by Bouček (1964) on pl. 37, fig. 8; Coll. NM L6273.

Type locality. - Švagerka near Zlíchov (Praha-Hlubočepy, Czech Republic).

Type horizon. - Daleje Shale (upper Emsian, Devonian).

Remarks. - Detailed description is given by Bouček (1964, pp. 142, 143).

Čeřinka sections. - Six shells from the Čeřinka quarry section (uppermost part of the Chýnice Limestone and lower part of the Daleje Shale with N. cancellata). 
Other occurrences in the Barrandian. - Císařská rokle section (the Daleje Shale and upper part of the Třebotov Limestone - layers with $N$. cancellata and $N$. richteri); Bouček (1964) noted also following localities: Praha-Holyně (Choteč Limestone with N. sulcata); Chýnice - Spodní mlýn (Choteč Limestone with N. sulcata); Vysoký Újezd (abandoned quarry - the Choteč Limestone with N. sulcata).

Stratigraphic range. - Upper Zlíchovian (Emsian) to lower Eifelian.

\section{Genus Costulatostyliolina Lardeux, 1969}

\section{Costulatostyliolina roemeri (Bouček, 1964)}

Holotype. - Specimen figured by Bouček (1964) on pl. 37, fig. 2; Coll. NM L6268.

Type locality. - Holyně - abandoned quarry (Prague, Czech Republic).

Type horizon. - Lower part of the Třebotov Limestone (Dalejan, upper Emsian).

Čerinka sections. - Tens of well-preserved complete shells from the Čeřinka quarry section (upper part of the Chýnice Limestone with $N$. barrandei, $N$. elegans, and N. cancellata) and from the Čeřinka hillside (upper part of the Chýnice Limestone with $N$. barrande $i+N$. elegans).

Other occurrences in the Barrandian. - Klukovice section (Daleje Shale with $N$. elegans); Pekárkův mlýn section (upper part of the Zlíchov Limestone with N. barrandei); Macháčkův lom near Hostim (Chýnice Limestone).

Stratigraphic range. - Upper Zlíchovian (Emsian).

Remarks. - Detailed description made by Bouček (1964, pp. 134-136).

\section{Costulatostyliolina termierae Lardeux, 1969}

Holotype. - Specimen figured by Lardeux (1969) on pl. 50, fig. 1; Institut de Paléontologie du Muséum d'Histoire naturelle de Paris.

Type locality. - La Grange, near Chalonnes (Armorican Massif).

Type horizon. - La Grange Limestone (lower Emsian, Lower Devonian).
Čerinka sections. - Tens of well-preserved shells (but none with protoconch) from the Čřinka quarry section (upper part of the Chýnice Limestone with N. elegans and N. cancellata).

Other occurrences in the Barrandian. - Chlupáč (1978) noted its occurrence in the Zlíchov and Chýnice limestones in his list of fossils but without any other locality information.

Stratigraphic range. - Upper Zlíchovian to lower Dalejan (Emsian).

Remarks. - Detailed description is given by Lardeux (1969, pp. 176-178). C. termierae differs from closely related $C$. roemeri by its sparse longitudinal ribs.

Order Styliolinida Lyashenko, 1955

\section{Genus Styliolina Karpinsky, 1884}

Type species. - Styliolina nucleata Karpinsky, 1884.

\section{Styliolina sp.}

Čerinka sections. - Hundreds of shells with different kinds of preservation; abundant through entire Čeřinka sections.

Other occurrence in the Barrandian. - Abundant through the whole Zlíchov and Daleje-Třebotov formations.

Remarks. - Straight smooth mostly conical shells disallowed any precise taxonomical identification and can contain more taxa together. At present state of knowledge specimens of this genus have no importance to detailed biostratigraphical research. For this reason shells of Styliolina sp. were not evaluated in presented analysis.

Order Gonionowakiida Lardeux, 1969

\section{Genus Gonionowakia Ruan \& Mu, 1983}

Type species. - Gonionowakia hexagona Ruan \& Mu, 1983.

\section{Gonionowakia sp.}

Čeřinka sections. - Several incomplete well-preserved shells from the Čeřinka quarry section (upper part of the Zlíchov Limestone with $N$. barrandei).

Other occurrences in the Barrandian. - Švagerka section (upper part of the Zlíchov Limestone with N. barrandei); Pekárkův mlýn section (upper part of the Zlíchov Limestone 
Lenka Ferrová et al. • Early Devonian Daleje Event in the Barrandian
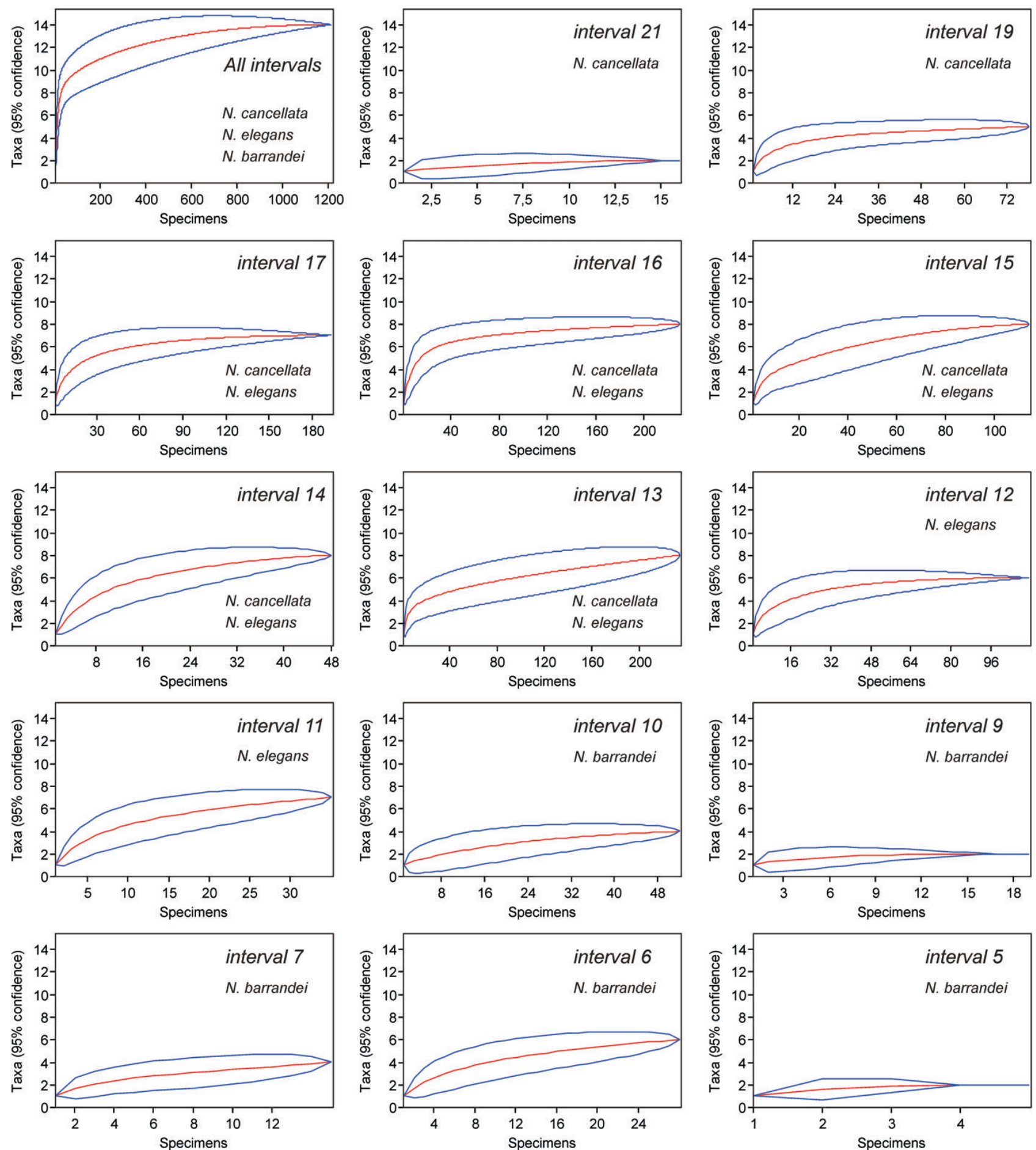

Figure 12. Čeřinka quarry section - comparison of taxonomic diversity in 15 tentaculite samples (intervals 5-21), using rarefaction analysis. By extrapolation, the curves indicate if further sampling would have increased the number of tentaculite species. The curves also show how many tentaculite species we would expect to find if the number of specimens in the sample were lower. Standard deviations are also shown.

with N. elegans); Císařská rokle section (upper Zlíchovian).

Stratigraphic range. - Upper Zlíchovian.
Remarks. - According to Ruan \& Mu (1983), fine shell with polygonal transverse section, sparse longitudinal ribs and sharp-ridged transverse rings characterize the genus Gonionowakia. 


\section{Genus Gonioviriatellina Ruan \& Mu, 1983}

Type species. - Gonioviriatellina cancellosa Ruan \& Mu, 1983.

\section{Gonioviriatellina sp.}

Čerinka sections. - Several incomplete, but well-preserved shells from the Čerinka quarry section (upper part of the Zlíchov Limestone with $N$. barrandei).

Other occurrences in the Barrandian. - Karlštejn - V Hlubokém Valley (upper part of the Zlíchov Limestone).

Stratigraphic range. - Upper Zlíchovian (Emsian).

Remarks. - Ruan \& Mu (1983) characterized this genus by fine shell with polygonal transverse section, sparse longitudinal ribs and undulated transverse rings.

\section{Proposal for a new tentaculite biostratigraphy}

The biostratigraphic correlation within the stratigraphic interval close to the Daleje Event (roughly corresponding to the boundary interval of the regional stages Zlíchovian and Dalejan) was traditionally based upon tentaculite biostratigraphy (Bouček 1964, Lukeš 1977). Tentaculite biostratigraphy has provided precise relative dating and correlation of disconformities, unconformities, hiatuses, and sedimentological changes among the Lower and Middle Devonian sections of the Barrandian. Within the stratigraphic interval around the Daleje Event, the tentaculite biostratigraphy provides a much higher stratigraphic resolution than biozonation, based on conodonts or goniatites. It is highly unlikely to considerably increase the stratigraphic resolution of goniatite biostratigraphy in the future, simply due to the fact that the goniatites generally occur rather rarely, and it will be impossible to find them in all of the studied beds. In contrast, it is easily possible to collect numerous determinable tentaculite shells in every limestone or shale bed. However, it has to be noted that the full potential of conodont biostratigraphy has not hitherto been evaluated in the Barrandian, and this is one of the main targets of the ongoing project.

Previously published tentaculite biozonal charts for the Barrandian area were composed of taxon-range zones (Bouček 1964). All beds close to the Daleje Event bear rich and diverse tentaculite assemblages (Figs 10 and 11). Species of the genus Nowakia Gürich, 1896 belong to the most abundant and easily determinable taxa; for this reason, they have been used for biostratigraphic correlations. Here, we review the existing biozones, and define one new subzone.
All of these biozones are defined here as interval zones. The main reason for this definition is the fact that new, more detailed biostratigraphic research has revealed co-occurrences of adjacent index biozones (e.g., N. barrandei + $N$. elegans; $N$. elegans $+N$. cancellata). An interval zone is much less affected by widespread and confusing overlaps and gaps among zonal index taxa. Here, each of redefined interval zones is applied in accordance with the stratigraphic "rules" proposed by the second edition of the International Stratigraphic Guide (Salvador 1994) and the third edition of Czech Stratigraphic Code (Chlupáč \& Štorch 1997). These biozones are defined by two bounding biohorizons, and named after the most significant traditional index species. Each biozone is further typified by a distinct tentaculite assemblage and its type section. This is just the first step in a redefinition of the tentaculite biozonal charts for the Barrandian area.

Taken together, usage of the biozones mentioned below as interval zones are the same as those mentioned by several authors (e.g., Lütke 1979, Kim 2011) but our usage differs from their common usage as range zones. In the following paragraphs, the basic data on the newly proposed tentaculite biostratigraphy of the Daleje Event interval are summarized. All of the biozones are listed in stratigraphic order.

\section{Nowakia barrandei Biozone}

This interval biozone is named after the characteristic species Nowakia barrandei Bouček \& Prantl, 1959, which is an internationally recognized zonal index fossil (Bouček 1964, Alberti 1993). The base of the barrandei Biozone is placed at the first appearance of $N$. barrandei, and its top at the first appearance of $N$. elegans (Barrande, 1867) in sense of Lukeš (1977). Several additional tentaculite species occur within the N. barrandei Biozone - Viriatellina pseudogeinitziana Bouček, 1964, V. hercynica Bouček, 1964, V. mui Alberti, 1993, Costulatostyliolina roemeri (Bouček, 1964), Stylionowakia cf. ligeriensis Lardeux, 1969, Gonionowakia sp., as well as the homoctenid Homoctenus hanusi (Bouček, 1964). The type section of the barrandei Biozone is at the Švagerka section.

\section{Nowakia elegans Biozone (including the barrandei-elegans Subzone)}

This interval biozone is named after the characteristic species Nowakia elegans (Barrande, 1867), which is a widely distributed zonal index fossil (Alberti 1993). The base of the elegans Biozone is placed at the first appearance of $N$. elegans, and the top of this biozone at the first appearance of $N$. cancellata (Richter, 1854) in sense of Lukeš (1977). 

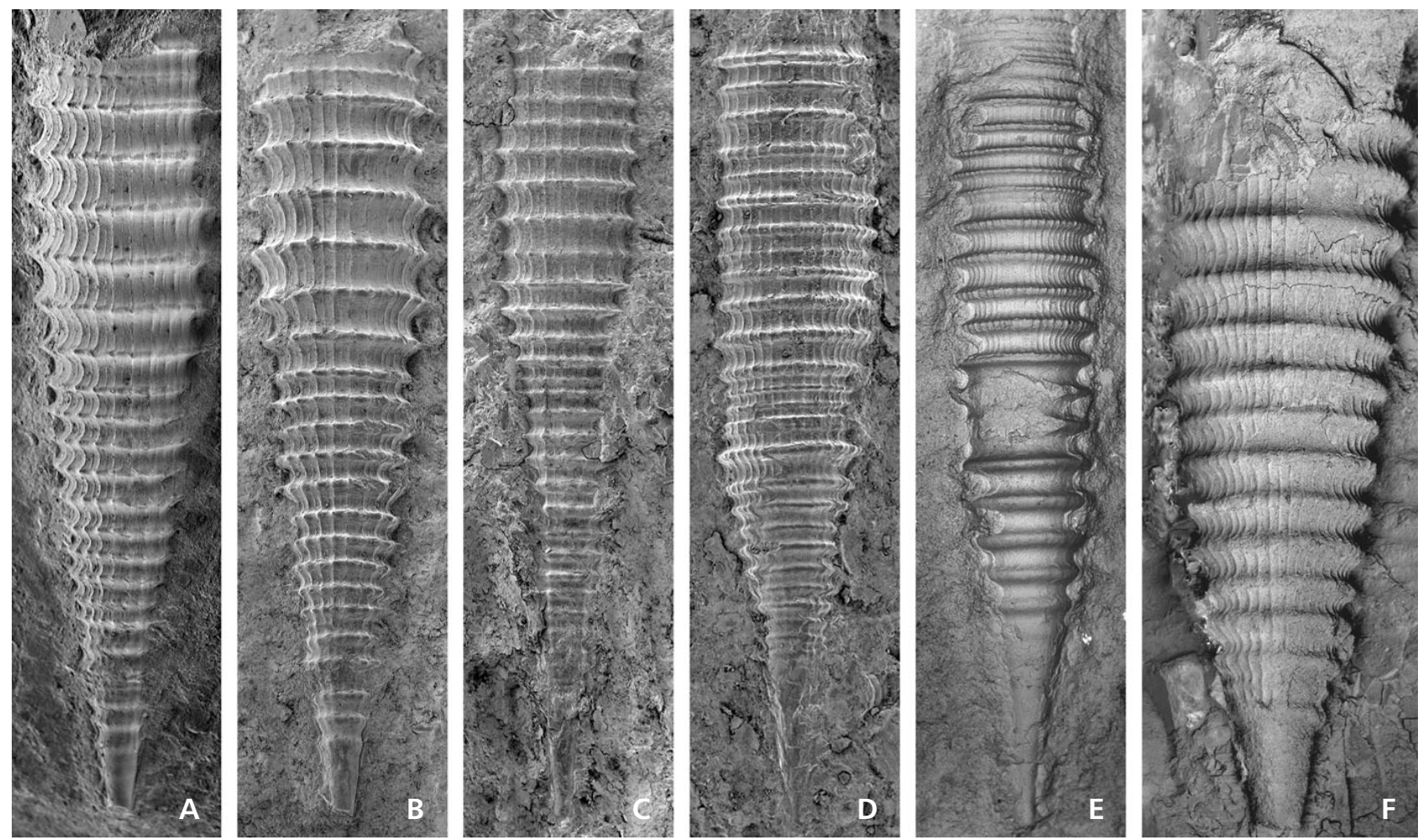

Figure 13. Shells of Nowakia elegans (A-C) and Nowakia barrandei (D-F). A, B - oblique lateral and lateral views of specimen PL333, Bubovice, Chýnice Limestone. • C - lateral view of specimen LF001, Čeřinka quarry, interval 17. • D - lateral view of specimen PL3719, Pekárkův mlýn. $\cdot$ E - lateral view of specimen PL12, Choteč, Zlíchov Limestone. $• F$ - lateral view of specimen LF002, Čeřinka hillside, interval 13. A, B × 20; C × 20; $\mathrm{D} \times 22 ; \mathrm{E} \times 17 ; \mathrm{F} \times 30$.

The lower part of the elegans Biozone is marked by its common occurrences of $N$. elegans and $N$. barrandei. Here, this level is established as a new barrandei-elegans Subzone within the N. elegans Biozone. Its base is also identical with the base of the elegans Biozone, and its top at the last appearance of $N$. barrandei. Several additional tentaculite species were found in both biozones; Costulatostyliolina roemeri (Bouček, 1964), and C. termierae Lardeux, 1969, are the most common species, together with the zonal index species within the elegans Biozone above the barrandei-elegans Subzone. However, C. roemeri also occurs in the barrandei-elegans Subzone and the underlying barrandei Biozone (Figs 11 and 12). Viriatellina pseudogeinitziana, V. hercynica, V. mui, Homoctenus hanusi, Dicricoconus sp., and Gonioviriatellina sp. are less frequent species of the elegans Biozone. The species C. termierae did neither occur in the barrandei-elegans Subzone nor in the underlying barrandei Biozone. The type section of the barrandei-elegans Subzone and the elegans Biozone is the Švagerka section; it is also well documented at the Čerinka hillside section (Fig. 3), as well as some other regions (Spain, Pamir Mts). Lütke (1979) also mentioned the co-occurrence of $N$. elegans and N. barrandei; however, he did not make any formal conclusions.

\section{Nowakia cancellata Biozone}

This interval biozone is named after the characteristic species Nowakia cancellata (Richter, 1854) sensu Lukeš (1977), which is an internationally recognized zonal index fossil (Bouček 1964, Alberti 1993). The base of the cancellata Biozone is placed at the first appearance of $N$. cancellata (in sense of Lukeš 1977), and the top of this biozone at the first appearance of $N$. richteri Bouček \& Prantl, 1959. The typical feature of the lower part of the cancellata Biozone is marked by the co-occurrences of $N$. cancellata and $N$. elegans. In the future, this level has good potential for the establishment of a new elegans-cancellata Subzone within the $N$. cancellata Biozone. However, very frequent occurrences of transitional forms (see above) between N. elegans and N. cancellata (Richter, 1854) in sense of Lukeš (1977) makes the definition of this subzone problematic before a detailed morphological analysis of all of these forms. Such an analysis must be based on a large amount of material (many tens or hundreds of wellpreserved shells), which has to be collected with the greatest stratigraphic resolution at several sections, in order to eliminate the influence of possible very short gaps in the sedimentation. At the current time, such material exists from only one section, as a by-product of the present study. 
The most common species in the cancellata Biozone, with the exception of the index taxon, are Costulatostyliolina roemeri and $C$. termierae. Their abundance is highest at the boundary of the elegans and cancellata biozones (Fig. 10). Viriatellina pseudogeinitziana, V. hercynica, V. mui, Stylionowakia cf. ligeriensis, Metastyliolina striatissima, Homoctenus hanusi, and Dicricoconus sp. are less frequent species of the cancellata Biozone. The type section of the cancellata Biozone is at the Císařská rokle near Srbsko.

\section{Features of new tentaculite biostratigraphy}

Redefinition of the tentaculite biostratigraphy of the Daleje Event interval is based on very large amounts of new materials (more than 1250 species determined) from two sections in the Bubovice area (Čeřinka quarry and Čeřinka hillside sections). The method used for the collection of this biostratigraphic data makes their quantitative evaluation possible. Results of rarefaction analyses of tentaculite occurrences in each of the studied beds (Fig. 12) suggest a rather good sampling density (i.e., there is a low probability that the studied beds contain significantly more tentaculite species). Collection of such a large amount of fossil materials revealed wider stratigraphic ranges for some tentaculite species. Costulatostyliolina roemeri, Viriatellina hercynica, V. mui, and V. pseudogeinitziana were first found in the Nowakia cancellata Biozone. The latter species, V. pseudogeinitziana, was also first recorded from the Nowakia elegans Biozone (also including the barrandei-elegans Subzone). The occurrence of $C$. termierae at the Čeřinka quarry section represents the first well-documented occurrence of this species in the Barrandian.

The most important result of the quantitative collection of tentaculites is not the improvement of the stratigraphic ranges of rare taxa, but an improvement of the tentaculite biostratigraphy. All previously published tentaculite biostratigraphic data are only based on a qualitative approach to the data collection. This qualitative approach, producing an absence/presence dataset, provided a much lower biostratigraphic resolution than the quantitative approach does, because many (or even most) of the data are only inferred from a single occurrence of a particular dacryoconarid species in any given bed. In addition, biostratigraphic data were not collected from all beds (see sections in Chlupáč et al. 1979). Our results clearly provide evidence for the co-occurrence of $N$. elegans and $N$. barrandei, making the definition of a new subzone possible. The new subzone was also recognized at South Tien Shan (Kim et al. 1978, 2011; Frýda, unpublished data) and in Spain (Montesinos \& Truyols-Massoni 1987, García-Alcalde et al. 1988). Lack of densely sampled sections within this stratigraphic interval, as well as the low number of tentaculite specialists are probably the main reasons for the missing records of co-occurrences of $N$. elegans and $N$. barrandei from other areas of the world. The duration of the barrandei-elegans Subzone was probably rather short, judging from a comparison of its thickness with those of other Emsian biozones.

\section{Discussion of transgression-regression history and faunal changes}

The present study is focused on the lithological appearance of the Daleje Event in areas with predominantly carbonate sedimentation. Application of the new high-resolution tentaculite biozonation to the newly gathered sedimentological data has resulted in a more detailed model of the transgression-regression history and faunal changes across the Daleje Event interval in the Barrandian. The latter model is discussed in detail in the following section.

\section{Nowakia barrandei Biozone}

In the Čeřinka area, the Zlíchov Limestone is typically developed as thin bedded, dark to light grey calcisiltites, with the characteristic abundant black cherts containing minor intercalations of calcareous shales almost throughout the entire thickness. Characteristic black cherts disappear a few meters below the boundary with the Chýnice Limestone, and the limestones become lighter and coarse. The uppermost part of the Zlíchov Limestone again becomes darker (increase in organic matter), but still with an increase in the amount of bioclasts (Fig. 2). This darker interval, belonging to the barrandei Biozone, was not documented at the Čřinka hillside section; probably because of the more weathered state of the Zlíchov Limestone, which has caused oxidation of the organic matter. About $2 \mathrm{~m}$ below the boundary with the Chýnice Limestone (i.e., just below above-mentioned dark interval), the Zlíchov Limestone bears a rich trilobite community dominated by Reedops decorus (Hawle \& Corda, 1847) and Zlichovaspis (Zlichovaspis) auriculata (Dalman, 1826) - determined by Petr Budil (see more detail on the stratigraphic distribution of both species in Chlupáč 1977, 1983; Budil et al. 2009). Recently, František Hörbinger (Prague) found additional trilobite species - Nephranomma modesta (Barrande, 1872), Crotalocephalus sternbergi sternbergi (Boeck, 1827), Harpidella (H.) kobayashii Přibyl \& Vaněk, 1981, Sculptoproetus sculptus sculptus (Barrarande, 1846), Zlichovaspis (Z.) vaneki Budil, Hörbinger \& Mencl, 2009, Koneprusia (K.) aff. chynicensis Vaněk \& Pek, 1987, Tropidocoryphe hermon (Šnajdr, 1977), Phacops (Pedinopariops) degener Barrande, 1852, and Lobopyge sp. (all 

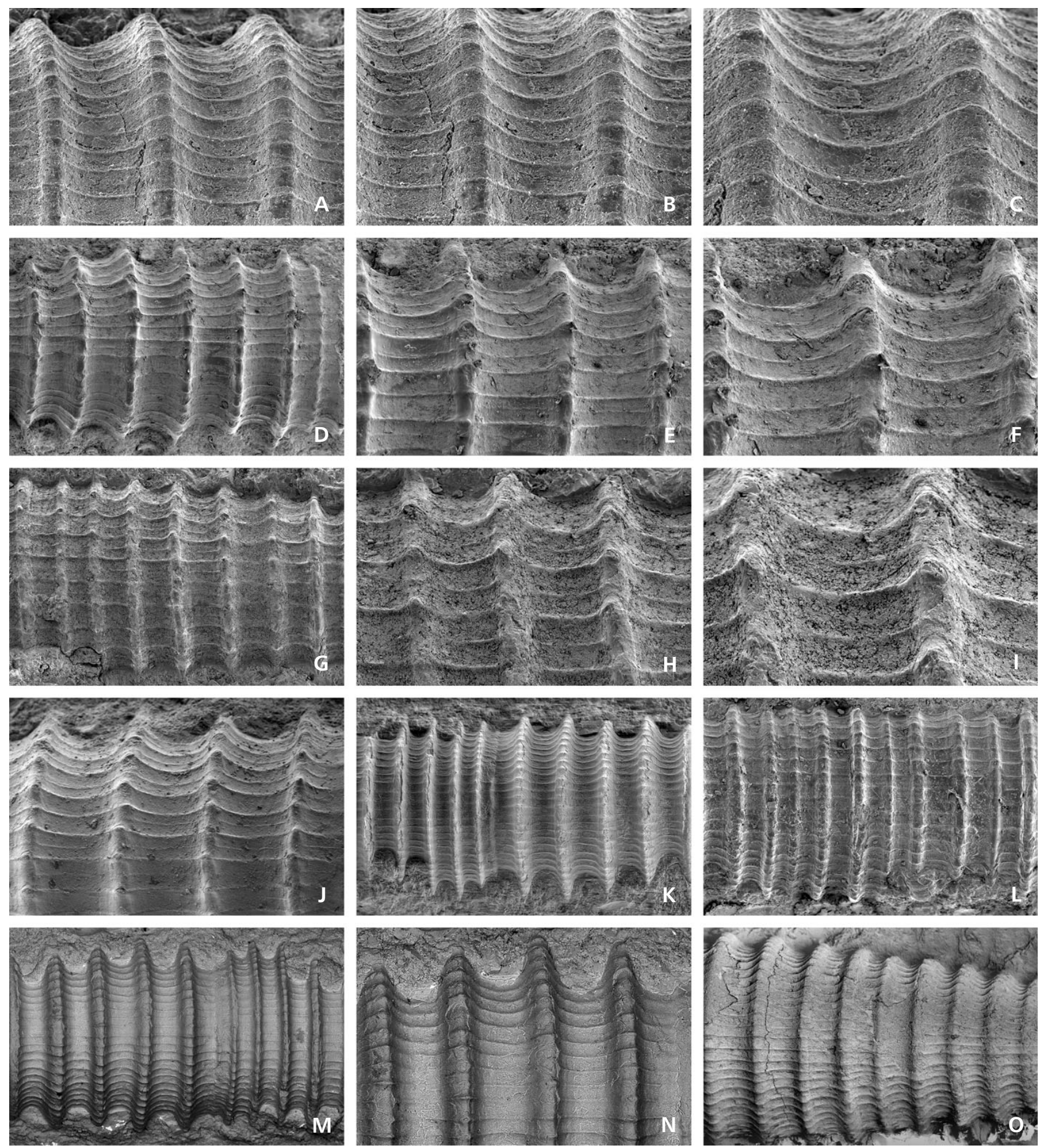

Figure 14. Detail views of shell ornamentation in Nowakia barrandei (A-C, K-O) and Nowakia elegans (D-J). Note secondary order ribs inserted between first order longitudial ribs bearing nodes at crossing with transversal rings in Nowakia elegans. $-\mathrm{A}-\mathrm{C}-$ Nowakia barrandei, specimen LF002, Čeřinka hillside, interval 13. D-F - Nowakia elegans, specimen PL333, Bubovice, Chýnice Limestone. • G-I - Nowakia elegans, specimen LF001, Čeřinka quarry, interval 17. • J - Nowakia elegans, specimen PL333, Bubovice, Chýnice Limestone. • K, M, N - Nowakia barrandei, PL12, Choteč, Zlíchov Limestone. $\bullet$ L - Nowakia barrandei, specimen PL3719, Pekárkův mlýn. $\bullet$ O - Nowakia barrandei, specimen LF002, Čeřinka hillside, interval 13. A × 90; B × 105; C × 160; D × 31; E × 58; F × 92; G × 42; H × 100; $\times 165 ; \mathrm{J} \times 50 ; \mathrm{K} \times 27 ; \mathrm{L} \times 35 ; \mathrm{M} \times 30 ; \mathrm{N} \times 55 ; \mathrm{O} \times 38$. 
determined by F. Hörbinger) - within these strata. This trilobite-rich horizon has been found in the same position at several other sections of Boubová Hill and the Kačák Valley areas (Frýda, unpublished data).

At the Čeřinka quarry section, the lower boundary of the Chýnice Limestone, with underlying Zlíchov Limestone, is gradual but rather sharp (thickness of the transition interval is only a few centimetres; Fig. 2). The lower part of the Chýnice Limestone at this section is formed by thick layers of white to light rosy recrystallized limestone beds (interval 8 to 10; Figs 3, 7). A very similar lithological development was documented at interval 4 at the Čeřinka hillside section (Fig. 3). The facies changes gradually from rosy unsorted floatstones with a calcisiltite matrix via poorly washed crinoidal packstones with pelletoids to rosy crinoidal grainstones. This was documented within the barrandei Biozone at the Čerinka hillside section (interval 8-14, lower part of the Chýnice Limestone; Fig. 3).

Occurrences of coarse-grained Zlíchov Limestone, or the transition to the lower part of the Chýnice Limestone in the barrandei Biozone, were recorded on all studied sections of the Barrandian area. At the Klukovice section (SW Prague; see Fig. 1), several beds of organoclastic, grey to pink limestones, with a total thickness of about 2 meters bear a rather rich trilobite fauna (Přibyl 1967, Šnajdr 1980, Chlupáč et al. 1979) together with the index tentaculite N. barrandei. Chlupáč et al. (1979) interpreted this stratigraphic interval as the "easternmost tongue of the Chýnice Limestone". New data from the Čeřinka sections are evidence that these fossil-rich beds are equivalent to the lower part of the Chýnice Limestone in the Čerinka area. The same development as at the Klukovice section has been documented (Prantl \& Svoboda 1950, Chlupáč et al. 1979, Chlupáč \& Lukeš 1999) at the Císařská rokle near Srbsko (see Fig. 17). The absence of cherts, as well as the occurrences of coarse-grained grey or pink-coloured limestones, are typical for the barrandei Biozone at the latter section. These limestone beds are also equivalent to the lower part of the Chýnice Limestone in the Čeřinka area.

The Chýnice Limestone is not developed in the SE part of the Barrandian area. The Švagerka section at PrahaZlíchov and Pekárkův mlýn near Solopisky are the best studied sections with such development (Kettner 1917; Kodym 1919; Kettner \& Kodym 1919; Chlupáč 1959; Chlupáč et al. 1979, 1998; Chlupáč \& Lukeš 1999). The characteristic cherts are missing at the top of the Zlíchov Limestone, and occurrences of the coarsely-grained limestone beds are typical for the barrandei Biozone of both sections (Fig. 17). However, the occurrence of calcareous shale has already been documented within this stratigraphic interval (Chlupáč et al. 1978, 1979). Coarse-grained as well as micritic limestone beds of the barrandei Biozone are rather fossiliferous. These beds at the Švagerka section are known as Barrande's "Schwagerka" locality, which provided rich coral and trilobite faunas (see history of this section in Kř́ž 1999 and stratigraphic data in Chlupáč 1957 and Chlupáč et al. 1979). It is noteworthy that the corral fauna of this level is in situ and does not show any traces of transport (Chlupác 1957). The latter author interpreted its occurrence as a biostrome formed at the appearance of the Chýnice Limestone in this part of the Barrandian.

The following stratigraphically significant conodonts and goniatites were documented within the barrandei Biozone: Polygnathus perbonus (Švagerka, Císařská rokle and Pekárkův mlýn sections; Chlupáč et al. 1979); Polygnathus gronbergi (Císařská rokle; Chlupáč et al. 1979); Erbenoceras solitarium (Barrande, 1865) (Pekárkův mlýn sections; Chlupáč et al. 1979). The conodont fauna of the barrandei Biozone of the Barrandian was hitherto not studied in detail, and the study of its stratigraphic distribution from the barrandei to cancellata biozones is one of main topics of this on-going project.

Lithological developments within the barrandei Biozone at both of the studied sections, Čeřinka hillside and Čeřinka quarry, is interpreted here as evidence for an upwardly shallowing trend, with an increasing intensity of sediment washing. Also, all available lithological data i.e. the disappearance of cherts and occurrences of coarsegrained Zlíchov Limestone with local developments of coral biostrome, gradual increases of the amount of rosy, unsorted crinoidal biosparite in the lower part of the Chýnice Limestone - from other Barrandian sections fits well with the latter interpretation.

\section{N. barrandei-N. elegans Subzone}

Lithological development within the newly established barrandei-elegans Subzone of the Nowakia elegans Biozone can be studied at the Švagerka and Čeřinka hillside sections.

The uppermost Zlíchov Limestone, intercalated by calcareous shales at the Švagerka section (beds 30 to 36 of Chlupáč et al. 1979), belongs to the barrandei-elegans Subzone. These beds provided a rich corral fauna in the past (Chlupáč 1957). In addition Chlupáč et al. (1979) mentioned a distinct faunal change at this level, where the typical Zlíchovian fauna (known at this section from beds 1 to 30) disappears. The discovery of biostratigraphically significant goniatite Palaeogoniatites lituus comes from the base of the barrandei-elegans Subzone at the Śvagerka section (Chlupáč et al. 1979, Chlupáč \& Turek 1983).

On the other hand, typical lithological types of the barrandei-elegans Subzone, occurring at the Čeřinka hillside section (intervals 15-18), include coarsely-bedded limestone beds formed mainly by unsorted floatstones, with umbrella structures and pluricolumnals of crinoids and limestone beds formed by in situ benthic organisms 

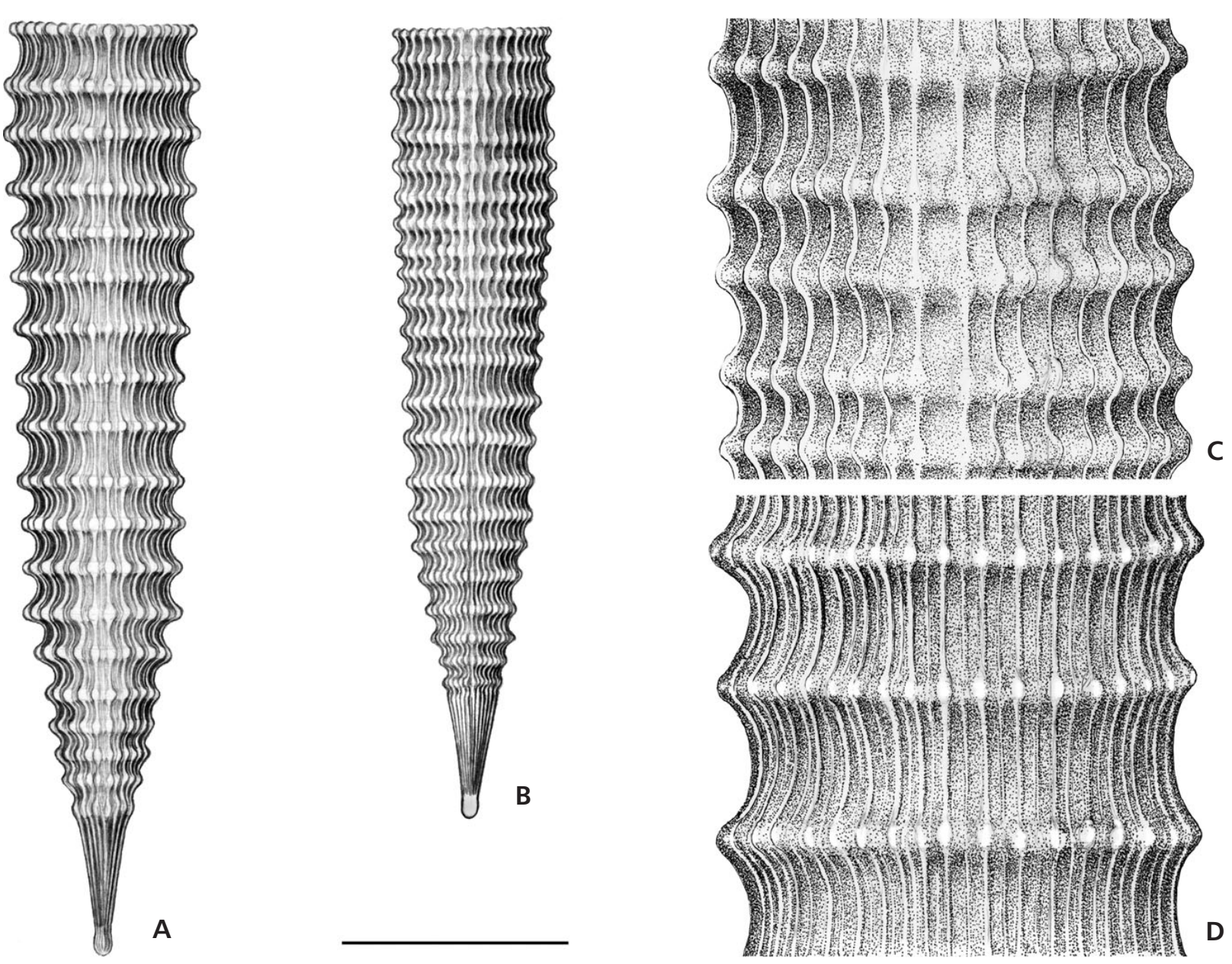

Figure 15. Reconstruction of shells in Nowakia elegans (A, D) and Nowakia barrandei (B, C). Details (C and D) show distinguishing character of the both species (note secondary order ribs inserted between first order longitudial ribs bearing nodes at crossing with transversal rings in Nowakia elegans). Scale equals to $0.6 \mathrm{~mm}$ for $\mathrm{A}, \mathrm{B}$ and to $0.2 \mathrm{~mm}$ for C, D.

(mainly corals). The fauna of this stratigraphic level is common and very highly diversified including trilobites, brachiopods, corals, cephalopods, gastropods, bivalves, and ostracods (Ferrová 2010, Ferrová et al. 2012). Numerical analysis of more than 2100 specimens belonging to more than 80 species of the barrandei and elegans biozones (collected by the senior author at the Čerinka hillside section) also revealed a distinct faunal change close to boundary of the barrandei and elegans biozones (Ferrová 2010, Ferrová et al. 2012, and Fig. 16; in prep.). The latter results are robust and statistically significant, and they support the earlier observations from deeper water environments made by Chlupáč et al. (1979).

There is no sedimentological record for the barrandei-elegans Subzone at the Čeřinka quarry section (Figs 3 and 7). The first bed bearing Nowakia elegans is bed 11 , which significantly differs from the underlying beds formed by light rosy neomorphized recrystallized limestones of the Nowakia barrandei Biozone (Figs 4 and 5). Sudden change in the isotopic composition of the carbonate carbon was also recorded just below the first occurrence of N. elegans (Ferrová 2010; Fig. 7). The absence of any common occurrence of N. elegans and N. barrandei, and the sharp lithological and geochemical changes just below the first occurrence of $N$. elegans at the Čerrinka quarry section (Figs 3 and 17) are interpreted as evidence for a sedimentological gap (and thus also a distinct sequence boundary) including at least the whole barrandei-elegans Subzone. Comparison of the lithology and thicknesses of the Chýnice Limestone at two geographically close sections, Čeřinka quarry and Čeřinka hillside sections, suggests that the above-mentioned gap probably also includes the upper part of the Nowakia barrandei Biozone at the Čerinka quarry section (Fig. 3).

The occurrence of beds of the barrandei-elegans Subzone at the Klukovice and Císařská rokle sections could not be tested due to the lack of biostratigraphic data at the boundary of $N$. barrandei and $N$. elegans biozones (Fig. 17). The occurrence of beds belonging to the barrandei-elegans Subzone at the Pekárkův mlýn section is 
presently under investigation. At this section, the first occurrence of Nowakia elegans was recorded at interval 18 (Chlupáč et al. 1979), just above the beds with the last shell of Nowakia cf. barrandei. Whether the barrandei-elegans Subzone is really missing at the Pekárkův mlýn section, or whether it is a sampling artefact (see methods section) will be revealed in the on-going research.

The present study revealed that the upper Zlíchovian regression culminated at the barrandei-elegans Subzone. Rich and highly diversified faunas connected with small bioherms are known from that time interval. Rich faunas and coral bioherms occurred not only in areas where the Chýnice Limestone was deposited (i.e., Bubovice area), but also in deeper environments (e.g., coral beds at the Švagerka section). The stratigraphical gap, including the whole barrandei-elegans Subzone (and likely also the top of the barrandei Biozone at the Čerinka quarry section) is the result of the culmination of the regression. It is noteworthy that this is the first evidence for a distinct stratigraphical gap in the Emsian succession of the Barrandian outside of the Koněprusy area.

Here, the lithological features within the barrandei-elegans Subzone are interpreted as the culmination of a regression trend, which is followed by a subsequent transgression from the top of the barrandei-elegans Subzone. Development of rich and highly diversified coral biostomes, newly documented at the Čerinka hillside section, as well as the existence of a sedimentologic gap at the Čerinka quarry section, strongly support this interpretation.

\section{Nowakia elegans Biozone above the barrandei-elegans Subzone}

The beginning of a transgression was documented in the barrandei-elegans Subzone. From that time, increasing depositions of the Daleje Shale in deeper environments, as well as more micritic red-coloured limestones of the upper part of the Chýnice Limestone in shallow environments are recorded. Sedimentation of calcareous Daleje Shale at this stratigraphic level was documented at the Švagerka, Pekárkův mlýn, Císařská rokle, and Klukovice sections (see Fig. 17; for details see Chlupáč 1959, Chlupáč et al. 1979, and Chlupáč \& Lukeš 1999). In the Koněprusy area, sedimentation of red crinoidal limestones, called the Suchomasty Limestone, started after a long hiatus including the whole lower Emsian (see Fig. 17; for details see Chlupáč 1959, Chlupáč et al. 1979). Here, the beginning of the deposition of the Suchomasty Limestone is dated to the elegans Biozone, but above the barrandei-elegans Subzone (Červený lom - Chlupáč et al. 1979; Voskop quarry - Lukeš in Frýda 1992).

The following stratigraphically important conodonts and goniatites were documented within the elegans Bio- zone above the barrandei-elegans Subzone: a transitional form of Polygnathus gronbergi and Po. laticostatus (Císařská rokle gorge; Chlupáč et al. 1979); Latericriodus b. beckmanni (Pekárkův mlýn; Chlupáč et al. 1979); Polygnathus laticostatus and Po. inversus (Červený lom; Chlupáč et al. 1979); Po. cf. inversus (Bubovice; Chlupáč et al. 1979); Mimosphinctes zlichovensis (Švagerka, Pekárkův mlýn; Chlupáč et al. 1979); Anetoceras sp. (Švagerka; Chlupáč et al. 1979); and Ivoites cf. hunsrueckianus (Erben, 1960) (Pekárkův mlýn section; Chlupáč et al. 1979, De Baets et al. 2009).

The lithological features of the elegans Biozone above the barrandei-elegans Subzone are interpreted as evidence for a continuous transgression trend.

\section{Nowakia cancellata Biozone}

During the cancellata Biozone, sedimentation was influenced by a continuous transgression which resulted in an increase of micrite and siliciclastic materials. A typical feature of the transgressive succession of the elegans to cancellata Biozones is the increase of both organic matter and iron oxides in the shales and carbonates.

Yellow to red coloured beds of unsorted tentaculite packstones intercalated with very thin calcareous shale layers (having a thickness of less than $1 \mathrm{~cm}$ ) typify the basal part of the cancellata Biozone at both Črrinka sections. After this, a $c a 1 \mathrm{~m}$ thick succession with a distinctly increasing trend in the amount of calcareous shales intercalating with homogeneous, unsorted, tentaculite wackestones to packstones is documented. The dominant fauna includes numerous tentaculites, brachiopods, and ostracods. Calcareous shales containing micritic nodules and thin nodular limestone beds represent the dominant lithological type, starting about 2 metres above the base of the cancellata Biozone and continuing upwards within this biozone. The term "transitional layers" between the Daleje Shale and Třebotov Limestone would be the best lithological term for this portion of the upper part of the cancellata Biozone, as was already noted by Chlupáč et al. (1979), who studied these stratigraphic levels in the Bubovice area.

The calcareous Daleje Shale forms the dominant lithological type everywhere in the NE, SE, and S parts of the Barrandian (e.g., Švagerka, Klukovice, Pekárkův mlýn, and Císařská rokle). However, in the areas $\mathrm{N}, \mathrm{W}$, and SW of the village of Bubovice, the Daleje Shale is not developed (Kodym 1924, Prantl \& Svoboda 1948, Chlupáč 1959). In this area, micritic beds belonging to the upper part of the Chýnice Limestone gradually change into the exclusively micritic and red-coloured Třebotov Limestone. Typical facies of the lower part of the Chýnice Limestone (as that found at both Čeřinka sections) reaches up to much 
higher levels stratigraphically. At the Macháčkův lom area (see Chlupáč et al. 1979, fig. 12), as well as at Boubová Hill and the Kačák Valley area it is not possible to select any useful lithological feature for a definition of a boundary between the Chýnice and Třebotov limestones because of their slow and gradual transition.

Lithological development of the Suchomasty Limestone, belonging to upper part of the elegans Biozone (i.e., above the barrandei-elegans Subzone), up to the cancellata Biozone in the Koněprusy area is basically the same as in those areas mentioned above. The term Suchomasty Limestone is somewhat unnecessary, and it has been kept only as a geographic name for the equivalent of the Chýnice and Třebotov limestones in the Koněprusy area. Chlupáč (1957) recognized this problem quite well, and placed the lower part of the Suchomasty Limestone to the facies of the Chýnice Limestone (Chlupáč 1957, p. 61: "K facii chýnických vápenců čítám i spodnější partie červenavých mramorů suchomastských a bezprostředního nadloží svrchních koněpruských vápenců...”). The term Suchomasty Limestone is used even though it can only be defined by its geographic position. The distance to any area with Suchomasty Limestone from the nearest occurrence of the Chýnice and Třebotov limestones is about $2 \mathrm{~km}$, which is of the same range as the distances amongst many sections of the Chýnice and Trrebotov limestones. Nevertheless, any redefinition of all of the above-mentioned lithostratigraphic names has to wait for a modern evaluation of facies distributions of all of the Emsian sections of the Barrandian.

The following significant conodonts and goniatites were documented in the Barrandian area within the cancellata Biozone: Latericriodus b. beckmanni (Hostim; Chlupáč et al. 1979); a transitional form of Polygnathus laticostatus and Po. gronbergi at the base of the cancellata Biozone, and Po. laticostatus at the top of the latter biozone (Císařská rokle; Chlupáč et al. 1979); Po. laticostatus and Po. inversus (Červený lom; Chlupáč et al. 1979); Gyroceratites gracilis; Mimagoniatites fecundus; Teicherticeras discordans (Pekárkův mlýn; Chlupáč et al. 1979, Chlupáč \& Turek 1983, Chlupáč \& Lukeš 1999); and Mim. fecundus (Čeřinka quarry).

The lithological development of the cancellata Biozone is interpreted as evidence for a continuous transgression trend.

\section{Implications for global Emsian stratigraphy}

Evaluation of the newly gathered palaeontological and sedimentological data from the Emsian successions of the Barrandian has some implications for the global Emsian stratigraphy. Becker (2007) summarized the results of the long-term activities of the International Subcommission
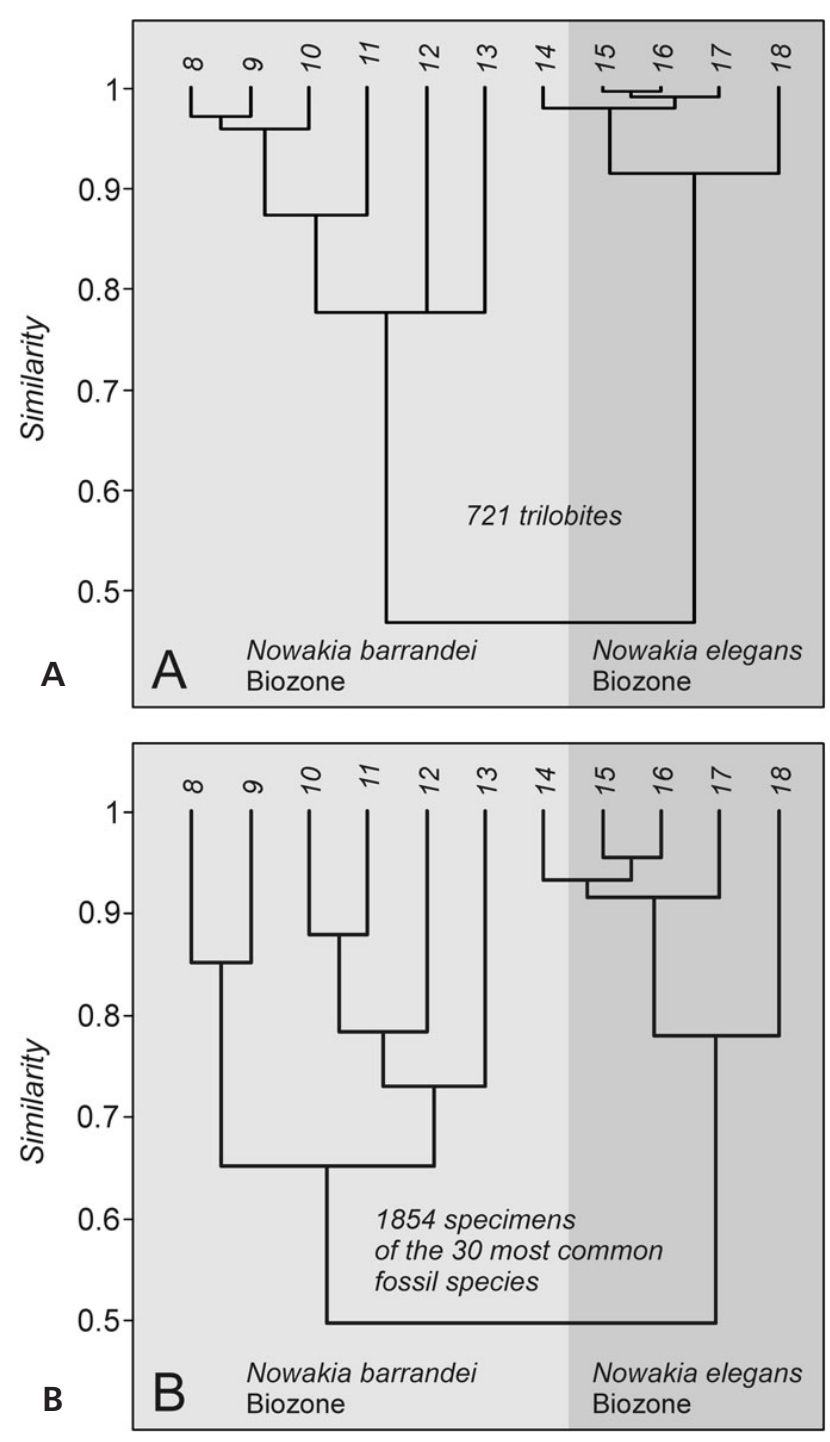

Figure 16. Čeřinka hillside section - stratigraphic intervals 8-18. Dendrogram based on clustering of Morisita's similarity index for abundance data using unweighed pair-group average algorithm. $\bullet$ A - clustering of 721 occurrences of the three most common trilobite species [Phacops (Pedinopariops) degener (Barr.), Orbitoproetus chynicensis (Přibyl) a Scabriscutellum (Cavetia) furciferum (Hawle \& Corda)]. - B - clustering of 1854 occurrences of the 30 most common fossil species (ex Ferrová 2010, and in preparation).

on Devonian Stratigraphy, focused on the division of the Emsian into two substages. This comprehensive report, together with some additional data on the stratigraphic ranges of "stratigraphically useful" groups such as the conodonts, goniatites, and tentaculites (see Subcommission on Devonian Stratigraphy Newsletters; http://unica2.unica.it/sds/) fully describe the problems of the Emsian substages or stages. In the following sections, we briefly comment on some of these problems, and propose some solutions which are based on the insights obtained from the present study. 


\section{What group to select for the boundary?}

This question could be changed to the question whether it is better to follow the tradition, or whether it would be preferable for the definition of the substage (stage) boundary to use any index fossil group, which provides the best stratigraphic resolution and is widely distributed. When we compare the three groups most commonly used as index fossils in the marine Devonian, i.e. conodonts, goniatites, and tentaculites, which have been discussed as the best potential groups for a splitting of the Emsian, we face the first problem - the ability to increase the biostratigraphic resolution in the future. There is no doubt that the Emsian goniatites represent a quickly evolving group of the Emsian invertebrates (De Baets et al. 2009; Klug et al. 2008, 2010; Monnet et al. 2011a, Korn \& Klug 2012), but their abundance is generally much lower than that of microfossils such as conodonts and dacryoconarid tentaculites. For a future increase in stratigraphic resolution, we suggest the selection of a group, which could be relatively easily found in almost every layer of many mid-Emsian successions. Undoubtedly, more sporadic occurrences of mid-Emsian goniatites create a preference for use of conodonts and dacryoconarid tentaculites as more useful groups for a definition of a substage (stage) boundary within the Emsian. The near facies independence of dacryoconarids makes them a stratigraphically very useful group, which has been somewhat neglected in the past years and deserves much more scientific attention.

On the other hand, any definition of biostratigraphic level just on the first appearance (FAD) of any species is a fundamental problem because the FADs of species are always diachronic. The diachronicity should be generally low and less than the stratigraphic resolution within small geographic areas, but it always exists. For this reason, usage of the FAD of single species for a definition of global biostratigraphic correlations seems to be problematic. In contrast to that, associations (co-occurrences of species) suffer much less from diachronicity (e.g. Monnet et al. 2011b). In this context, here proposed level for splitting the Emsian (base of the barrandei-elegans Subzone) should be slightly better solution than previously proposed level (base of the cancelata Biozone), because the proposed boundary is based on co-occurrence of two tentaculite species with rather short duration. Nevertheless, in the future a biostratigraphic scheme combining various groups like tentaculites, conodonts and goniatites would be really desirable for a stable Emsian biozonation.

\section{Relationship between the substage boundary and extinction events}

Many major stratigraphic boundaries were selected at levels of distinct faunal turnover, typically at the level of the radiation of a new group of marine organisms. In this context, it should be noted that a radiation event is a much better biostratigraphic marker than an extinction event. The main reason for this is the fact that the abundance of most marine species is generally higher just after their origins than before their extinction (e.g., Signor-Lipps effect; Signor \& Lipps 1982). Graptolites are a very good example illustrating this "rule". The level of extinction of the so-called Anetoceras fauna is very frequently used as quite important for testing of the suitability of any biostratigraphic marker for a definition of a mid-Emsian substage (stage) boundary (e.g., Chlupáč \& Lukeš 1999, p. 96; Becker 2007). Becker (2007, p. 30) stated, referring to this issue, that "Unfortunately, even this polygnathid [...] is well below the upper Anetoceras faunas". Here, we see several basic problems. First, according to our knowledge, there is currently no published evidence that the extinction of the so-called Anetoceras fauna (or the Daleje Bioevent by House 1985) represents a single synchronous event. This analysis will be complicated by the fact that some anetocerids have a very limited geographic distribution, and the fossil record of the Anetoceras fauna is not generally as rich as that of the conodonts or tentaculites. Additionally, Ockam's razor can be applied to this issue, i.e., it is not really possible to properly prove the exact stratigraphic position of the extinction level. Secondly, there is no data evidencing that the extinction rate and intensity during the crisis of the Anetoceras fauna were higher than that in the case of the Zlíchovian faunal turnover (barrandeilelegans Biozone boundary). Taken together, we suggest abandoning the use of the relationship between the Anetoceras fauna extinction and the stratigraphic position of any useful mid-Emsian biostratigraphic marker as an important criterion for the evaluation of its suitability for a definition of a mid-Emsian substage boundary.

Figure 17. Schematic model (upper left) showing the biostratigraphic position and geographic relationship of the lithological units of the Daleje Event interval in the Barrandian. All biostratigraphically well-dated sections are figured in the lower part of the figure, as well as their positions in the schematic model. In the upper right part of the figure a new proposal for the biostratigraphic and lithostratigraphic divisions is given. Recent data suggests inclusion of the lithologically distinct "Upper Chýnice Limestone" into the Daleje-Třebotov Formation, because this lithological unit is the product of a new sedimentary cycle started by the Daleje Event transgression. However, formal redefinition of the lithostatigraphic units of the Daleje Event interval must not be done until after a full re-evaluation of all available sections in the Barrandian. Future analysis will show if the unit informally named here (i.e., the "Upper Chýnice Limestone") should be formally established, or whether it belongs to the Třebotov Limestone of the Daleje-Třebotov Formation. 
Lenka Ferrová et al. • Early Devonian Daleje Event in the Barrandian

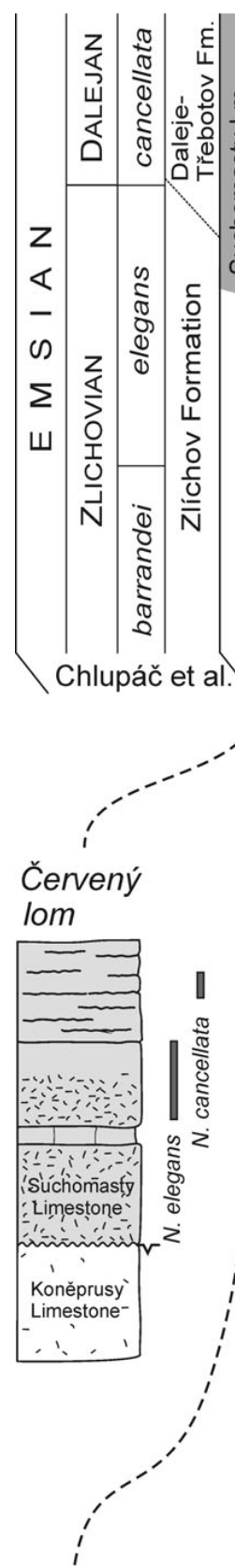

Čeřinka

quarry

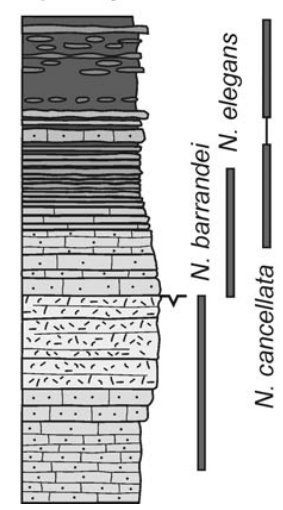

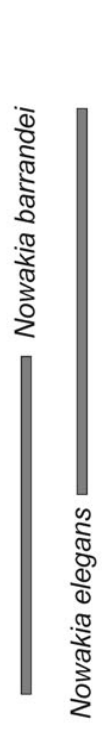

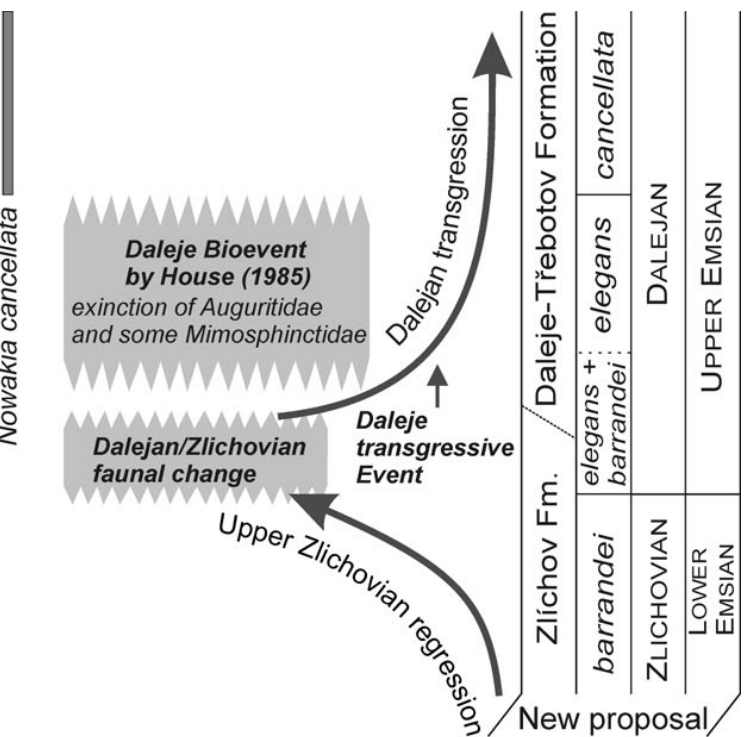

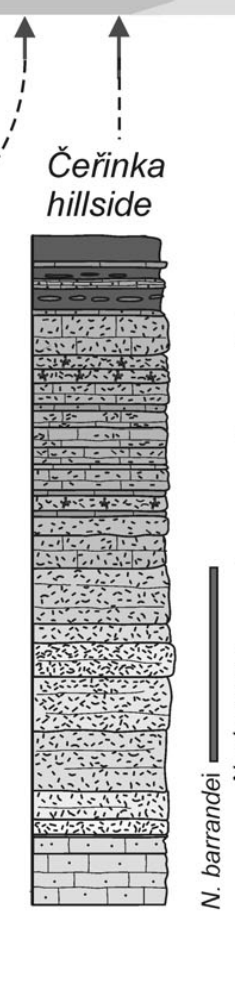
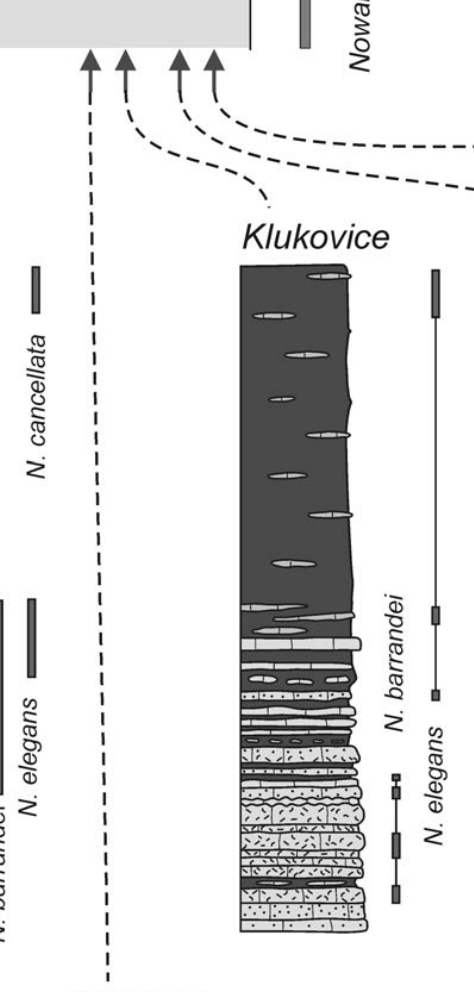

\section{Císařská rokle}

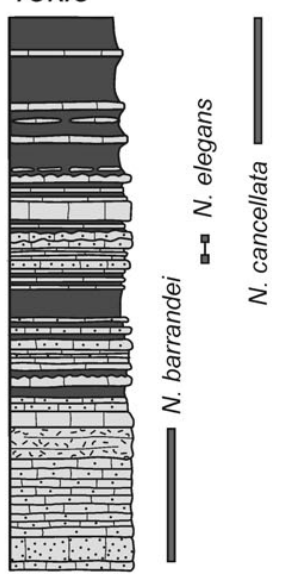

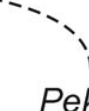

Pekárkín
mlýn

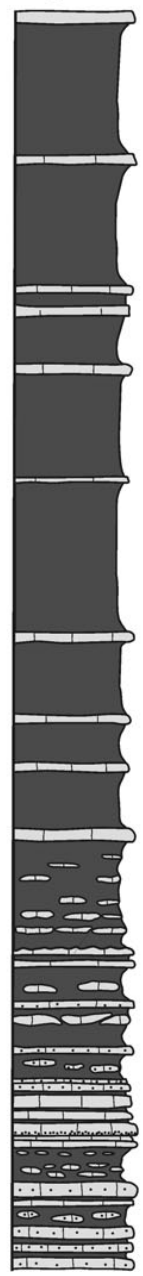

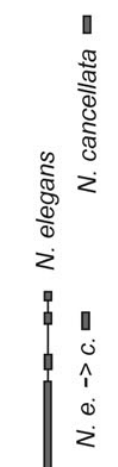

\section{Švagerka}

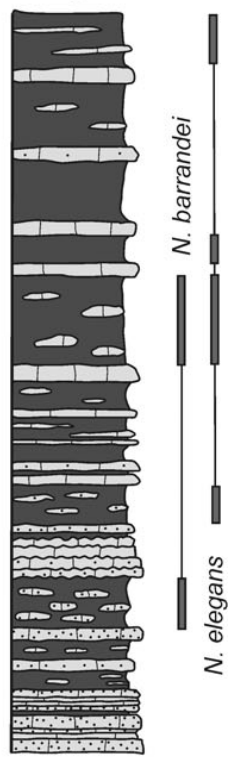

ine-grained detrital to micritic limestones

\section{S'- coarse detrital mainly} crinoidal limestones (\&i) detrital limestones with "in situ"

distinctly nodula limestones

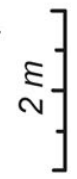




\section{Nowakia elegans and the substage (stage) boundary}

Originally, the lower Dalejan boundary was proposed at the first appearance of Nowakia cancellata (see Chlupác 1976, 1982; Chlupáč \& Lukeš 1999). The use of $N$. cancellata for a definition of a mid-Emsian substage boundary has been discussed by several authors (see Chlupáč \& Lukeš 1999, and Becker 2007 for both advantages and disadvantages of this choice). Evaluation of the new biostratigraphic data from the Barrandian leads us to redefine the lower Dalejan boundary (FAD of the N. elegans) as well as to propose the base of the Nowakia elegans Biozone as a better level for the definition of the Emsian substage (stage) boundary (i.e., the lower/upper Emsian boundary). The advantages and disadvantages of this choice are summarized in the following paragraphs. We consider this level to be a good choice for the following reasons:

1. There is a general agreement that the substage boundary should lie close to the level of the supposedly global transgressive Daleje Event (Becker 2007, p. 29). As shown by the present study, the upper Zlíchovian regression culminates at the base of the Nowakia elegans Biozone (within the barrandei-elegans Subzone). The beginning of the Daleje transgression is just above the lower boundary of the Nowakia elegans Biozone, and thus is much older than the base of the Nowakia cancellata Biozone. The Barrandian is the type area for the Daleje Event.

2. Nowakia elegans is easily distinguishable from the older Nowakia barrandei: These two species differ by a qualitative morphological characteristic, namely the absence or presence of secondary ribs (Figs 14 and 15). In contrast to the younger $N$. cancellata, there are no known transitional forms between $N$. barrandei and N. elegans. This fact was not only corroborated by the study of a large amount of specimens gathered by the senior author over the last few years, but also by a study of all available collections from the Barrandian area, made over the past 40 years by Pavel Lukeš. Similar results were obtained by Kim (personal communication to JF, 2008), who has studied large tentaculite collections from the Tien Shan.

3. It is noteworthy that the co-occurrence of Nowakia barrandei and $N$. elegans was also recorded at Tien Shan (Kim 2011) and in Spain (Montesinos \& Truyols-Massoni 1987, García-Alcalde et al. 1988), which indicates the likely high usefulness of this newly proposed subzone for intercontinental correlation. Additionally, co-occurrences of index species enhance the stratigraphic reliability of stratigraphic units.

4. Nowakia elegans is a widely distributed species (as is $N$. cancellata), and it occurs in both the carbonate as well as the clastic dominated environments, which increases its usefulness for global stratigraphic correlations. Also, in the
Barrandian, N. elegans is known to occur in both of the above-mentioned environments.

5. Nowakia elegans, as with all planktonic organisms, is very abundant and can generally be found in most sediment layers. This feature will be helpful for the future need to increase the biostratigraphic resolution.

6. The base of the Nowakia elegans Biozone is close to the boundary of the conodont biozones (Polygnathus nothoperbonus Mawson, 1987 and Polygnathus inversus Klapper \& Johnson, 1975; see data in Mawson 1987; Mawson \& Talent 2003; Kim et al. 2008, 2012), which increases the usefulness of both the conodont and tentaculite levels for global stratigraphic correlations. Additionally, this yields the possibility of independent testing by using the two different fossil groups.

7. The base of the Nowakia elegans Biozone appears to be close to the level of a distinct faunal turnover (end of the Zlíchovian fauna; see the discussion above), which was recorded in benthic as well as planktonic and nektonic groups.

8. The stratigraphical range of Nowakia elegans is much shorter than that of the conodont and goniatite species, which have been suggested as markers for a definition of the Emsian substage boundary.

The main disadvantages of using the base of the Nowakia elegans Biozone as a possible level for any definition of an Emsian substage (stage) boundary are the following:

1. Although Nowakia elegans is a widely distributed species, there are not many detailed studies on its stratigraphic ranges in relationship to other biostratigraphically "significant" taxa. One exception is Tien Shan, where rather dense biostratigraphic data for different groups have recently been published (Kim 2011, Sennikov 2011).

2. At the present time, there is very little information on conodont biostratigraphy of the majority of Emsian sections in the Barrandian, which complicates any improvement of the composite conodont-tentaculite biostratigraphy. Nevertheless, detailed conodont studies of mid-Emsian sections in the Barrandian are one of the main topics of this on-going project, together with the addition of goniatite data.

3. FADs of species always suffer from their diachronicity. Associations of species are more reliable and should be preferred for the definition of (sub-)stage boundaries. Therefore, the combination of stratigraphic data of tentaculitids, conodonts and ammonoids are the most promising approach to produce a robust stratigraphic framework.

Taken all together, with the present state of knowledge, using the base of the Nowakia elegans Biozone as a possible level for the definition of an Emsian substage (stage) boundary appears to us to be a choice, which must be considered. This choice has the same significance as all 
hitherto suggested boundaries. Nevertheless, additional biostratigraphic studies will have to be performed before a final decision can be made.

\section{Acknowledgements}

This research was supported by a grant from the Czech-American Cooperation Program (Kontakt ME08011), the Grant Agency of the Czech Republic (GACR 210/12/2018), and a grant from the Czech Geological Survey (3346). This is our contribution to IGCP 591 and IGCP 596. We wish to thank the following of our colleagues and friends who helped us during the last several years in the field, in labs, and with their suggestions: Jan Buchar (Lomy Mořina, s.r.o.), Petr Budil, Pavel Čáp and Štěpán Manda (Czech Geological Survey, Prague), Barbora Frýdová (Crop Research Institute, v.v.i., Prague), Michal Hejna (Velkolom čertovy schody, a. s., Tmaň), Jindřich Hladil and Leona Koptíková (Institute of Geology AS CR, v.v.i., Prague), František Hörbinger, Michal Kubajko and Radek Labuta (palaeontologists cooperating with the National Museum, Prague), Michal Mergl (University of West Bohemia, Pilsen), as well as Lukáš Potyš and Radim Vaculovič (Lomy Mořina, s.r.o.). The paper benefited from the reviews by Christian Klug (Universität Zürich) and Jindřich Hladil (Institute of Geology AS CR), who improved the manuscript significantly.

\section{References}

AlberTi, G.K.B. 1993. Dacryoconaride und homoctenide Tentaculiten des Unter- und Mittel-Devons I. Courier Forschungsinstitut Senckenberg 158, 1-229.

AlberTi, G.K.B. 1998. Planktonische Tentakuliten des Devon. III. Dacryoconarida Fisher 1962 aus dem Unter-Devon und oberen Mitteldevon. Palaeontographica, Abteilung A 250(1-3), 1-46.

Algeo, T.J. \& Scheckler, S.E. 1998. Terrestrial-marine teleconnections in the Devonian: Links between the evolution of land plants, weathering processes and marine anoxic events. Philosophical Transactions of the Royal Society B 353, 113-130. DOI 10.1098/rstb.1998.0195

Вамвасн, R.K. 1999. Energetics in the global marine fauna: A connection between terre strial diversification and change in the marine biosphere. Geobios 32(2), 131-144. DOI 10.1016/S0016-6995(99)80025-4

BANDEL, K. 1997. Higher classification and pattern of evolution of the Gastropoda. Courier Forschungsinstitut Senckenberg 201, 57-81.

BARRANDE, J. 1846a. Notice préliminaire sur le Systême silurien et les Trilobites de Bohême. 97 pp. Hirschfeld, Leipzig.

Barrande, J. 1846b. Noveaux Trilobites. Supplément à la Notice préliminaire sur le Systême silurien et les Trilobites de Bohême. 40 pp. J.G. Calve, Prague.

BARRANDE, J. 1852. Systême silurien du centre de la Bohême. lère partie. Recherches paléontologiques. Vol. I. Crustacès: Trilobites. 935 pp. Privately published, Prague.

BARRANDE, J. 1867. Systême silurien du centre de la Bohême. lère partie. Recherches paléontologiques. Vol. II. Classe des
Mollusques, Ordre des Céphalopodes, lère série. 712 pp. Prague \& Paris.

BARRANDE, J. 1872. Systême silurien du centre de la Bohême. Vol. I, Supplement I. 647 pp. Prague \& Paris.

BeCKER, R.T. 2007. Emsian substages and the Daleje event - a consideration of conodont, dacryoconarid, ammonoid and sealevel data. Subcommission on Devonian Stratigraphy Newsletter 22, 29-32.

Becker, R.T., De Baets, K. \& Nikolaeva, S. 2010. New ammonoid records from the Lower Emsian of the Kitab reserve (Uzbekistan) - preliminary results. Subcommission on Devonian Stratigraphy Newsletter 25, 20-28.

BeCKer, R.T. \& Kirchgasser, W.T. (eds) 2007. Devonian Events and Correlations. Geological Society of London, Special Publication 278, 1-280.

BerkyovÁ, S., FrÝdA, J. \& Lukeš, P. 2007. The first documentation of unsuccessful predation on the Middle Paleozoic plankton. Acta Palaeontologica Polonica 52(2), 407-412.

BoEck, C.P.B. 1827. Notiser til Laeren om Trilobiterne. Magazin for Naturvidenskaberen 1.

BouČEK, B. 1964. The Tentaculites of Bohemia. 215 pp. Czechoslovak Academy of Sciences, Prague.

BOUČEK, B. \& PrantL, F. 1959. Význam tentakulitů pro stratigrafii stř̌edočeského devonu. Časopis Národního muzea, $\breve{R} a d a$ prírodovědná 128(1), 5-7.

BoučEK, B. \& Prantl, F. 1961. Über einige neue Tentaculiten-Gattungen aus dem böhmische Devon. Věstník Ústředního ústavu geologického 36, 385-388.

Budil, P., Hörbinger, F. \& Mencl, R. 2009. Lower Devonian dalmanitid trilobites of the Prague Basin (Czech Republic). Earth and Environmental Science Transactions of the Royal Society of Edinburgh 99, 61-100. DOI 10.1017/S1755691009006161

Carls, P. \& Valenzuela-Ríos, J.I. 2007. From the Emsian GSSP to the early Late Emsian - correlations with historical boundaries. Subcommission on Devonian Stratigraphy Newsletter 22, 24-27.

Carls, P., Slavík, L. \& Valenzuela-Ríos, J.I. 2008. Comments on the GSSP for the basal Emsian stage boundary: the need for its redefinition. Bulletin of Geosciences 83(4), 383-390. DOI 10.3140/bull.geosci.2008.04.383

CHLuPÁČ, I. 1954. Předběžná zpráva o stratigrafických výzkumech středočeského spodního devonu (Preliminary report on the stratigraphic investigation of the Central Bohemian Devonian). Věstník Ústředního ústavu geologického 29, 133-140. [in Czech]

CHLuPÁČ, I. 1955a. Stratigrafická studie o nejstarších devonských vrstvách Barrandienu (Stratigraphical study of the oldest Devonian beds of the Barrandian). Sborník Ústředního ústavu geologického, Oddíl geologický21(2), 91-224. [in Czech with English summary]

CHLuPÁČ, I. 1955b. Stratigrafický výzkum spodní části branických vápenců v Barrandienu (Stratigraphic investigation of the lower parts of the Braník Limestone in the Barrandian). Věstník Ústředního ústavu geologického 30, 59-73. [in Czech]

CHLuPÁČ, I. 1956. Nové poznatky o stratigrafii středočeského devonu (New information on the stratigraphy of the Central Bohemian Devonian). Věstník Ústředního ústavu geologického 31, 233-243. [in Czech] 
ChlupÁČ, I. 1957. Faciální vývoj a biostratigrafie středočeského spodního devonu. Sborník Ústředního ústavu geologického, Oddíl geologický 23, 369-485.

CHLUPÁČ, I. 1959. Faciální vývoj a biostratigrafie břidlic dalejských a vápenců hlubočepských (eifel) ve středočeském devonu (Facial development a biostratigraphy of Daleje Shale and Hlubočepy Limestone /Eifelian/ in the Devonian of Central Bohemia). Sborník Ústředního ústavu geologického, Oddíl geologický 25, 445-511. [in Czech with English summary]

Chlupéč, I. 1976. The Bohemian Lower Devonian stages. Newsletters on Stratigraphy 5(2/3), 168-189.

ChlupÁČ, I. 1977. The phacopid trilobites of the Silurian and Devonian of Czechoslovakia. Rozpravy Ústředního ústavu geologického 43, 1-172.

ChLuPÁČ, I. 1981. Stratigraphic terminology of the Devonian in Central Bohemia (Barrandian area, Czechoslovakia). Věstník Ústředního ústavu geologického 56, 263-270.

Chlupáč, I. 1982. The Bohemian Lower Devonian stages. Courier Forschungsinstitut Senckenberg 55, 345-400.

CHLUPÁČ, I. 1983. Trilobite assemblages in the Devonian of the Barrandian area and their relations to palaeoenvironment. Geologica et Palaeontologica 17, 45-73.

ChlupÁč I. I996. Neptunian dykes in the Koněprusy Devonian: Geological and palaeontological observations. Věstník Českého geologického ústavu 71(3), 193-208.

Chlupéč́, I., HavlíčeK, V. \& KŘíž, J. 1998. Palaeozoic of the Barrandian. 183 pp. Czech Geological Survey, Prague.

Chlupáč, I. \& Kukal, Z. 1988. Possible global events and the stratigraphy of the Palaeozoic of the Barrandian (Cambrian-Middle Devonian, Czechoslovakia). Sborník geologických věd, Geologie 43, 83-146.

Chlupéč, I. \& Lukeš, P. 1999. Pragian/Zlíchovian and Zlíchovian/Dalejan boundary sections in the Lower Devonian of the Barrandian area, Czech Republic. Newsletters on Stratigraphy 37, 75-100.

ChlupÁČ, I., Lukeš, P. \& ZikmundovÁ, J. 1978. The Lower-Middle Devonian boundary beds in the Barrandian area, Czechoslovakia. 78 pp. Ústřední ústav geologický, Praha.

Chlupáč, I., LuKeš, P. \& ZikmundovÁ, J. 1979. The Lower/Middle Devonian boundary beds in the Barrandian area. Geologica et Palaeontologica 13, 125-156.

ChluPÁČ, I. \& ŠTorch, P. (eds) 1997. Zásady české stratigrafické klasifikace, 3. vydání (Principles of the Czech stratigraphic classification). Věstník Českého geologického ústavu 72(2), 193-204. [in Czech]

ChlupÁČ, I. \& TuREK, V. 1983. Devonian goniatites from the Barrandian area. Rozpravy Ústředního ústavu geologického 46, $1-159$.

Dalman, J.W. 1827. Om Palaeaderna, eller de sa kallade trilobiterna. Kungliga Svenska Vetenskapsakademiens Handlingar 1826, 113-52, 226-94.

De Baets, K., Klug, C. \& Korn, D. 2009. New Anetoceratinae (Ammonoidea, Early Devonian) from Germany with a revision of their genera. Neues Jahrbuch für Geologie und Paläontologie, Abhandlungen 252, 361-376. DOI 10.1127/0077-7749/2009/0252-0361

De Baets, K., Klug, C., Korn, D. \& Landman, N.H. 2012. Evolutionary trends in ammonoid embryonic development. Evolution 66(6), 1788-1806. DOI 10.1111/j.1558-5646.2011.01567.x
De Baets, K., Klug, C. \& Plusquellec, Y. 2010. Zlíchovian faunas with early ammonoids from Morocco and their use for the correlation between the eastern Anti-Atlas and the western Dra Valley. Bulletin of Geosciences 85(2), 317-352.

DOI 10.3140/bull.geosci.1172

ERben, H.K. 1960. Primitive Ammonoidea aus dem Unterdevon Frankreichs und Deutschlands. Neues Jahrbuch für Geologie und Paläontologie, Abhandlungen 110, 1-128.

Ferrová, L. 2010. Biostratigraphy, sedimentology, and paleoecology of the Chýnice Limestone at Čr řnka locality near Bubovice. 96 pp. Master thesis, Charles University, Prague.

Ferrová, L., FrÝdA, J. \& LuKEŠ, P. 2012. High-resolution tentaculite biostratigraphy as a key for progress in the Emsian stratigraphy: new data on the Daleje Event from the Barrandian (Bohemia). $34^{\text {th }}$ International Geological Congress, 3569. Brisbane.

FIALA, F. 1946. Dernière phase du volcanisme diabasique dans la Dévonien de la Bohême centrale. Věstník Státního geologického ústavu Československé republiky 21(3-6), 157-174.

FISHER, D.W. 1962. Small conoidal shells of uncertain affinities, 98-143. In Moore, R.C. (ed.) Treatise on Invertebrate Paleontology, Part W, Miscellanea. Geological Society of America and University of Kansas Press, New York.

FrÝDA, J. 1992. Mode of life of a new onychochilid mollusc from the Lower Devonian of Bohemia. Journal of Paleontology 66(2), 200-205.

FrÝDA, J. 2001. Discovery of a larval shell in Middle Paleozoic subulitoidean gastropods with description of two new species from the Early Devonian of Bohemia. Věstník Českého geologického ústavu 76(1), 29-37.

FRÝDA, J. 2012. Phylogeny of Paleozoic gastropods inferred from their ontogeny, 395-435. In TALENT, J.A. (ed.) Earth and Life - Global Biodiversity, Extinction Intervals and Biogeographic Perturbations Through Time, Series: International Year of Planet Earth. 1100 pp. Springer. DOI 10.1007/978-90-481-3428-1_12

FrÝdA, J. \& BlodgetT, R.B. 2004. New Emsian (late Early Devonian) gastropods from Limestone Mountain, Medfra B-4 quadrangle, west-central Alaska (Farewell terrane), and their paleobiogeographic affinities and evolutionary significance. Journal of Paleontology 78(1), 111-132.

DOI 10.1666/0022-3360(2004)078<0111:NELEDG >2.0.CO;2

Frýda, J., Ferrová, L., Berkyová, S. \& Frydová, B. 2008b. A new Early Devonian palaeozygopleurid gastropod from the Barrandian (Bohemia) with notes on the phylogeny of the Loxonematoidea. Bulletin of Geosciences 83(1), 93-100. DOI 10.3140/bull.geosci.2008.01.093

Frýda, J., Racheboeuf, P.R., Frýdová, B., Ferrová, L., Mergl, M. \& Berkyová, S. 2009. Platyceratid gastropods - stem group of patellogastropods, neritimorphs or something else? Bulletin of Geosciences 84(1), 107-120.

DOI 10.3140/bull.geosci.1125

FrÝDA, J., NÜTZEL, A. \& Wagner, P.J. 2008a. Paleozoic gastropods, 239-270. In Ponder, W. \& Lindberg, D.L. (eds) Phylogeny and Evolution of the Mollusca. 488 pp. University of California Press, Berkeley \& Los Angeles, California.

García-Alcalde, J.L., Montesinos, J.R., Truyols-Massoni, M., García-Lopez, S., Arbizu, M.A. \& Soto, F. 1988. The Silurian and Devonian of the Palentian Domain (NW Spain). Revista de la Sociedad Geologica de España 1(1-2), 7-13. 
GÜRICH, G. 1896. Das Paläozoicum in polnischen Mittelgebirge. Verhandälungen der Russischen Kaiserlichen Gesselschaft zu St. Petersburg II, 32, 1-539.

Hammer, Ø., Harper, D.A.T. \& Ryan, P.D. 2001. PAST: Paleontological Statistics Software Package for Education and Data Analysis. Palaeontologia Electronica 4(1), 1-9, http://palaeo-electronica.org/2001_1/past/issue1_01.htm.

HavlíčEK, V. \& KuKal, Z. 1990. Sedimentology, benthic communities and brachiopods in the Suchomasty (Dalejan) and Acanthopyge (Eifelian) Limestones of the Koněprusy area (Czechoslovakia). Sborník geologických věd, Paleontologie 31, 105-205.

HAVLÍČEK, V. \& VANĚK, J. 1996. Brachiopods and trilobites in the Chýnice Limestone (Emsian) at Bubovice (Čeřinka hillside; Prague Basin). Palaeontologia Bohemiae 2, 1-16.

Hawle, J. \& CoRda, A.J.C. 1847. Prodrom einer Monographie der böhmischen Trilobiten. 176 pp. J.G. Calve, Prague.

HLADIL, J. 2004. Environmental relationships of endolithic microborers and substrates in Barrandian limestones of Devonian age, Czech Republic. In Mikuláš, R. (ed.) $4^{\text {th }}$ International Bioerosion Workshop, IBW-4, Abstract Book, Prague, p. 26.

Hladil, J., Vondra, M., Čejchan, P., Vích, R., Koptíková, L. \& SLAVÍK, L. 2010. The dynamic time-warping approach to comparison of magnetic-susceptibility logs and application to Lower Devonian calciturbidites (Prague Synform, Bohemian Massif). Geologica Belgica 13(4), 385-406.

House, M.R. 1985. Correlation of mid-Palaeozoic ammonoid evolutionary events with global sedimentary perturbations. Nature 313, 17-22.

House, M.R. 1989. Analysis of mid-Palaeozoic extinctions. Bulletin de la Société géologique de Belgique 98, 99-107. DOI 10.1038/313017a0

KaRPINSKY, A.P. 1884. Die fossilen Pteropoden am Ostabhange des Urals. Mémoire de l'Académie des Sciences 7, ser. 32(1). [In KARPINSKY, A.P. 1945. Travaux scientifiques 1, 443-460.]

KaUfmann, B. 2006. Calibrating the Devonian time scale: A synthesis of U-Pb ID-TIMS ages and conodont stratigraphy. Earth-Science Reviews 76(3-4), 175-190. DOI 10.1016/j.earscirev.2006.01.001

KeTtNER, R. 1917. Příspěvek ku stratigrafii branických vápenců (Gg1) nejbližšího okolí pražského. Rozpravy České akademie věd a umění, Třída II 26, 1-25.

Kettner, R. \& Kodym, O. 1919. Nová stratigrafie Barrandienu. Časopis Musea Království českého 93, 47-55.

Kim, A.I. 2011. Devonian tentaculites fron the Kitab State Geological Reserve (Zeravshan-Gissar mountainous area, Uzbekistan). News of paleontology and stratigraphy 15, 65-82. [in Russian]

Kim, A.I., Erina, M.V., Kim, I.A., Salimova, F.A., MeshchanKINA, N.A. \& RAKhmonov, U.D. 2012. The Pragian-Emsian Event and subdivision of the Emsian in the Zinzilban and Khodzha-Kurgan sections. Subcommission on Devonian Stratigraphy SDS Newsletter No. 27, 38-41.

Kim, A.T., Yolkin, E.A., Erina, M.V. \& Gratsianova, R.T. 1978. Type section of the Lower and Middle Devonian boundary beds in the middle Asia. 54 pp. Field session of the International Subcomission of Devonian system. A guide to field excursions.

Kim, A.I., Yolkin, E.A., Erina, M.V., Kim, I.A., Meshchankina, N.A., Salimova, F.A., Karimova, F.S., Rakhnmonova, U.D.,
Tsmeyrek, E.S., Bakharev, N.K., Izokh, N.G., Kipriyanova, T.P., Овut, O.T. \& Sennikov, N.V. 2008. Devonian sequences of the Kitab Reserve area. In YoLKIN, E.A., KIM, A.I. \& Talent, J.A. (eds) Field Excursion Guidebook. 100 pp. Publishing House of SB RAS, Novosibirsk.

KLAPPER, G. 1977. Lower-Middle Devonian boundary conodont sequence in the Barrandian area of Czechoslovakia. Časopis pro mineralogii a geologii 22(4), 401-406

KLAPPER, G. \& Johnson, D.B. 1975. Sequence in conodont genus Polygnathus in Lower Devonian at Lone Mountain, Nevada. Geologica et Palaeontologica 9, 68-83.

Klapper, G., Ziegler, W. \& Mashkova, T.V. 1978. Conodonts and correlation of Lower-Middle Devonian boundary beds in the Barrandian area of Czechoslovakia. Geologica et Palaeontologica 12, 103-116.

KLUG, C. \& Korn, D. 2004. The origin of ammonoid locomotion. Acta Palaeontologica Polonica 49(2), 235-242.

Klug, C., Kröger, B., Korn, D., Rucklin, M., Schemm-Gregory, M., De Baets, K. \& MAPES, R.H. 2008. Ecological change during the early Emsian (Devonian) in the Tafilalt (Morocco), the origin of the Ammonoidea, and the first African pyrgocystid edrioasteroids, machaerids and phyllocarids. Palaeontographica, Abteilung A 283, 4-6, 83-U58.

Klug, C., Kröger, B., Kiessling, W., Mullins, G.L., Servais, T., FrÝdA, J., Korn, D. \& TuRner, S. 2010. The Devonian Nekton Revolution. Lethaia 43, 465-477. DOI 10.1111/j.1502-3931.2009.00206.x

KoDYM, O. 1919. Slivenecké mramory a jejich poměr k vápencům bránickým (G-g1). Rozpravy České akademie věd a umění, Třída II 28(16), 1-6.

KoRn, D. \& KLUG, C. 2012. Palaeozoic ammonoids - Diversity and development of conch morphology, 491-533. In TALENT, J.A. (ed.) Earth and Life - Global Biodiversity, Extinction Intervals and Biogeographic Perturbations Through Time, Series: International Year of Planet Earth. 1100 pp. Springer, Dordrecht \& New York. DOI 10.1007/978-90-481-3428-1_15

KREJČí, J. 1877. Geologie čili nauka o útvarech zemských se zvláštním ohledem na krajiny českoslovanské. 1035 pp. Jan Krejčí, Praha.

KŘiž, J. 1999. Geologické památky Prahy. 278 pp. Český geologický ústav, Praha.

LARDEUX, H. 1969. Les tentaculites d'Europe occidentale et d'Afrique du nord. 238 pp. Editions du Centre National de la Recherche Scientifique, Paris.

LUKEŠ, P. 1977. Some index tentaculites (Nowakiidae) from the Lower/Middle Devonian boundary beds of the Barrandian. Časopis pro mineralogii a geologii 22(1), 19-28.

LÜTKE, F. 1979. Biostratigraphic significance of the Devonian Dacryoconarida. Special Papers in Paleontology 23, 281-289.

Lyashenko, G.P. 1957. Novyje roda devonskich tentaculitov. Doklady Akademii nauk SSSR, 116, 141-144.

Lyashenko, G.P. 1955. Novye dannye o systematike tentakulitov, novakiy i styliolin. Autoreferat doklada. Bulletin of Moscow Society of Naturalists, Ser. Geol. 29(3), 94-95.

MANDA, Š. \& FRÝDA, J. 2010. Silurian-Devonian boundary events and their influence on cephalopod evolution: evolutionary significance of cephalopod egg size during mass extinctions. Bulletin of Geosciences 85(3), 513-540.

DOI 10.3140/bull.geosci.1174 
Mergl, M. \& Ferrová, L. 2009. Lingulate brachiopods from the Chýnice Limestone (upper Emsian, Barrandian; Czech Republic). Bulletin of Geosciences 84(3), 525-546. DOI 10.3140/bull.geosci.1143

Mawson, R. 1987. Early Devonian conodont faunas from Buchan and Bindi, Victoria, Australia. Palaeontology 30, 251-297.

Mawson, R. \& Talent, J.A. 2003.Conodont faunas from sequences on or marginal to the Anakie Inlier (Central Queensland, Australia) in relation to Devonian transgressions. Bulletin of Geosciences 78(4), 335-358.

Monnet, C., De Baets, K. \& Klug, C. 2011a. Parallel evolution controlled by adaptation and covariation in ammonoid cephalopods. BMC Evolutionary Biology 11(115), 1-21.

DOI 10.1186/1471-2148-11-115.

Monnet, C., Klug, C., Goudemand, N., De Baets, K. \& Bucher, H. 2011b. Quantitative biochronology of Devonian ammonoids from Morocco and proposals for a refined unitary association method. Lethaia 44(4), 469-489.

DOI 10.1111/j.1502-3931.2010.00256.x

Montesinos, J.R. \& Truyols-Massoni, M. 1987. La Fauna de Anetoceras y el límite Zlichoviense-Dalejiense en el Dominio Paleontino (NO. de España). Cuadernos do Laboratorio Xeolóxico de Laxe 11, 191-208.

NütZel, A. 1998. Über die Stammesgeschichte der Ptenoglossa (Gastropoda). Berliner Geowissenschaftliche Abhandlungen, Reihe E 26, 1-229.

NüTZEL, A. \& FRÝDA, J. 2003. Palaeozoic plankton revolution: Evidence from early gastropod ontogeny. Geology 31(9), 829-831. DOI 10.1130/G19616.1

Nützel, A., FrýdA, J., Yancey, T.E. \& Anderson, J.R. 2007a. Larval shells of Late Palaeozoic naticopsid gastropods (Neritopsoidea: Neritimorpha) with a discussion of the early neritimorph evolution. Paläontologische Zeitschrift 81(3), 213-228.

NütZel, A., LehNert, O. \& FrÝdA, J. 2006. Origin of planktotrophy - evidence from early molluscs. Evolution and Development 8(4), 325-330. DOI 10.1111/j.1525-142X.2006.00105.x

NÜTZEL, A., LEHNERT, O. \& FRÝDA, J. 2007b. Origin of planktotrophy - evidence from early molluscs: a response to Freeman and Lundelius. Evolution and Development 9(4), 312-317.

PřiBYL, A. 1967. Příspěvek k poznání rodu Eremiproetus R. et E. Richter, 1919 a Vicinopeltis gen. n. (Trilobita). Časopis Národního muzea, Oddíl přírodovědný 136(4), 219-224.

PřIBYL, A. \& VANĚK, J. 1981. Preliminary report on some new trilobites of the family Harpetidae Hawle et Corda. Časopis pro mineralogii a geologii 26(2), 187-193.

RICHTER, R. 1854. Thüringische Tentaculiten. Zeitschrift der Deutschen geologischen Gesellschaft 6(2), 275-290.

RuAN, Y.P. \& Mu, D.C. 1983. Gonionowakiidae - A new dacryoconarid family, with reference to the classification of the order Dacryoconarida at a family level. Bulletin of Nanjing Institute of Geology and Palaeontology, Academia Sinica 6, 173-184.

SAlah, A.A. 1976. Phylogenie und Biostratigraphie devonischer Nowakiidae (Dacryoconarida). 128 pp. Fachbereichs Geowissenschaften der Universität Hamburg, Hamburg.
Salvador, A. 1994. International Stratigraphic Guide. 214 pp. Geological Society of America, Boulder, Colorado.

Schindler, E., Brocke, R., Fatka, O., Jansen, U. \& Weddige, K. 2003. Paläontologie, Biostratigraphie und Fazieswechsel im Grenzbereich Unter-/Ober-Emsium - das Referenzprofil Císařská rokle im Prager Becken (Unter-Devon, Barrandium, Tschechische Republik), 141. In BRACHERT, T.C. (ed.) BiodiversitätEndogene und exogene Hintergründe. Terra Nostra 5.

Sennikov, N.V. (ed.) 2011. Paleontology and stratigraphy of the Zeravshan-Gissar mountainous area (Uzbekistan). News of paleontology and stratigraphy 15, Supplement to journal "Geologiya i geofizika", 1-246. [in Russian]

Seuss, B., Nützel, A., Scholz, H. \& FrÝdA, J. 2012. The Paleozoic evolution of the gastropod larval shell: larval armor and tight coiling as a result of predation-driven heterochronic character displacement. Evolution \& Development 14(2), 212-228. DOI 10.1111/j.1525-142X.2012.00536.x

SignoR, P.W. \& BRETT, C.E. 1984. The mid-Paleozoic precursor to the Mesozoic marine revolution. Paleobiology 10(2), 229-245.

SignOR III, P.W. \& LiPPS, J.H. 1982. Sampling bias, gradual extinction patterns, and catastrophes in the fossil record, 291-296. In Silver, L.T. \& Schultz, P.H. (ed.) Geological implications of impacts of large asteroids and comets on the Earth. Geological Society of America, Special Publication 190.

Svoboda, J. \& PrantL, F. 1947. O stratigrafii a tektonice staršího paleozoika v okolí Třebotova. Sborník Státního geologického ústavu Republiky československé 14, 281-324.

Svoboda, J. \& Prantl, F. 1948a. O stratigrafii a tektonice staršího paleozoika v okolí Chýnice. Sborník Státního geologického ústavu Republiky československé 15, 1-40.

Svoboda, J. \& Prantl, F. 1948b. Stratigraficko-paleonologický a tektonický výzkum údolí Berounky u Srbska a Kačáku u Hostimi. Věstník Státního geologického ústavu 23, 200-206.

Svoboda, J. \& PrantL, F. 1951. Zpráva o novém výzkumu údolí Kačáku mezi Sv. Janem pod Skalou a Hostimí. Věstník Státního geologického ústavu 26, 361-370.

Svoboda, J., Prantl, F. \& Kukal, Z. 1957. Vysokoprocentní vápence Barrandienu. Geotechnica 23, 51-78.

ŠNAJDR, M. 1977. New genera of Proetidae (Trilobita) from the Barrandian, Bohemia. Věstník Ústředního ústavu geologického 52(5), 293-298.

ŠNAJDR, M. 1980. Bohemian Silurian and Devonian Proetidae (Trilobita). Rozpravy Ústředního ústavu geologického 45, $1-323$.

VANĚK, J. 1998. Rare trilobites from the Chýnice Limestone (Emsian, Prague Basin, Czech Republic). Palaeontologia Bohemiae 4, 6 -9.

VANĚK, J. \& PeK, I. 1987. Genus Koneprusia (Trilobita) from the Devonian of Central Bohemia. Časopis pro mineralogii a geologii 32(3), 261-270.

WalcotT, C.D. 1886. Second contribution to the studies on the Cambrian faunas of North America. Bulletin of the United States Geological Survey 30, 1-365.

Vodrážková, S., Frýda, J., Suttner, T.J., Koptíková, L. \& Tonarová, P. 2012. Environmental changes close to the Lower-Middle Devonian boundary, the Basal Choteč event in the Prague Basin (Czech Republic). Facies.

DOI 10.1007/s10347-012-0300-x 